\title{
A taxonomic bibliography of the South American snakes of the Crotalus durissus complex (Serpentes, Viperidae)
}

\author{
PAULO E. VANZOLINI and MYRIAM E.V. CALLEFFO \\ ${ }^{1}$ Museu de Zoologia, Universidade de São Paulo, Cx. Postal 42694, 04299-970 São Paulo, SP, Brasil \\ ${ }^{2}$ Instituto Butantan, Laboratório de Herpetologia, São Paulo, SP, Brasil \\ Manuscript received on October 26, 2001; accepted for publication on November 9, 2001; \\ contributed by PAULO E. VANZOLINI
}

\begin{abstract}
A survey is made of the taxonomic literature on South American rattlesnakes (genus Crotalus, family Viperidae). Two main areas are emphasized: the attribution of the names proposed in the eighteenth century by Linnaeus and Laurenti, and the current scheme of division in subspecies.

The attribution of names is examined based on the original descriptions and on relevant previous and contemporary literature. The presently adopted scheme, proposed by Klauber $(1941,1972)$ is found not entirely satisfactory, but reasonable enough - besides being hallowed by use.

The scheme of geographical differentiation, intrinsically important and with broad practical implications (differentiation of the venom) is found to be the culmination of a long series of deficient analyses, and in urgent need of proper investigation.
\end{abstract}

Key words: Crotalus durissus, Viperidae, geographical differentidation, differentiation of the venom.

\section{INTRODUCTION}

The assemblage of forms currently known as the subspecies of Crotalus durissus embodies some of the most interesting problems in Neotropical herpetology. They constitute a set of closely related parapatric forms, whose mutual relations and mechanisms of speciation, never yet properly studied, are conceivably of great theoretical interest. Additionally, on the practical side, geographical differentiation has been demonstrated in the chemistry of the venom, a fact of far-reaching and urgent medical as well as zoological implications. In contradistinction with these attractive features, studies on the group have been few and undistinguished. The

Correspondence to: P.E. Vanzolini

E-mail: vanzo@usp.br old literature is confused and confusing: it has been analyzed at several reprises by Klauber (q.v.i.), who proposed a sensible, if rather uninspired scheme, generally adopted. Geographical differentiation, obvious and intense, was deplorably dealt with by Hoge (1966), whose cursory work has been accepted in the literature without evaluation, culminating in the thorough but uncritical compilation by McCranie (1993).

The very extensive range of the group and the relatively large size of the individual snakes raise considerable logistic problems to a comprehensive revision. We have undertaken a piecemeal review of the Brasilian forms, using mostly the materials at hand in our institutions and aiming initially at a formal traditional taxonomic treatment, to be followed, if feasible, by investigations in more depth 
of the evolutionary aspects. Thus the present review of papers of systematic or distributional importance.

We have organized the matter in four sections: (i) a history of the systematic concepts in what they refer to South America; (ii) papers that contain precise geographic information, listed in Appendix 1; and (iii) papers that, although mentioning South American rattlers, contain no information useful in the present context, so denoted in the References. There is one additional section on chromatism, and a concise gazetteer.

\section{A HISTORY OF CONCEPTS AND NAMES}

Usually, the review of old literature is evocative and pleasant. Not here: the literature on South American Crotalus is very uneven and uncommonly unrewarding. Rattlesnakes are charismatic animals, surrounded by legend, and from early times attracted the attention of travelers of diverse scientific competence, who tended to write copiously on them. These, mostly naive, travel reports constitute the raw materials of practically all the early literature (Curran 1935). Specimens, with or without locality data, were surprisingly rare in collections, and sparingly reported upon.

Linnaeus (1758: 214) diagnosed the genus Crotalus as snakes having (widened) ventral scales, small or large (actually divided or undivided) subcaudals, and a terminal rattle, or crepitaculum. He included three species, all three marked with the "Mars sign", $\bigcirc$, that at the time already signified in the general literature "male", but that in the context of the Systema Naturae indicated instead that the species had poison fangs (Linnaeus 1758: 194195). For each species Linnaeus gave scale counts (ventrals and subcaudals), country of origin ("habitat') and, in two cases, summary notes on color pattern. He also included bibliographic references, to his own pre-Systema work and to contemporary authors. The species were:

1. Crotalus horridus, 167 ventrals +25 subcaudals, from "America". References are given to Linnaeus's own 'Mus. Ad. Fr.', better known as Mu- seum Regis, to Bradley (1721), and to Seba (17341765). Additional notes referred to its venomousness, to its eating birds and squirrels on trees, to its being predated upon by hogs and to the existence of a natural antidote ("senega", or milkwort, root, a Polygala). All these are well-known parts of North American folklore, early reported in Europe by Kalm (1752).

2. C. dryinas, $165+30$ scales, from "America", with a laconic note on color pattern, and a reference to Amoenitates Academicae 1: 217 (Linnaeus 1749). This is a mistaken reference: the page mentioned is part of a botanical dissertation on "Peloria". However, in the same Amoenitates, in the chapter entitled Museum Principis, p. 578, $n^{\circ} 24$, is described an "Anguis (Crotalophorus) scutis abdominalibus CLXV, caudalibus XXX', which is certainly $C$. dryinas. Eight references are made to the literature. Five are useless to us: Ray (1693), Seba (1734-1765), Jonstone (1650-1653), Nieremberg (1635) and Olearius (1674). Three other citations are potentially useful, to Marcgrave (1648), Piso (1648) and Hernandez (1651) - but in fact they are contradictory. The former two would point to northeastern Brasil, the latter to Mexico. One juvenile ("barely 2 feet long") was available, gray with yellowish dorsal spots; no doubt a faded specimen.

3. C. durissus, with $172+24$ scales, was referred to Kalm (1752, 1753), to Gronovius (1763-1764) and to the Amoenitates 1: 500. This last citation is again a mistake: the page mentioned (part of the thesis Surinamensia Grilliana) contains reference to one Amphisbaena and to Anilius scytale, not to Crotalus. Instead, on page 510 of the same Surinamensia Grilliana there is a "Crotalophorus scutis abdominalibus CLXXII, scutis caudalibus XXI, paribusque squamarum III', which is certainly C. durissus. References in the Amoenitates are to Jonstone (16501653), to Nieremberg (1635), to Olearius (1674) to vol. 1, part 1, of the "Museum Imperiale Petropolitanus"' (1742), and to Vincent (1726). None of them is of any present use. Additionally, Swedish scientists who reviewed surviving Linnean herpetologi- 
cal types (Lönnberg 1896, Andersson 1900, Holm 1957) make it clear that no rattlesnake type is extant.

It is evident that Linnaeus recognized three species of rattlesnakes, based on actual specimens, but that his understanding of these was confused and did not go beyond the generic level. It is a conspicuous fact in the history of the knowledge about rattlesnakes that their being large venomous snakes sporting a rattle did for a long time overshadow more systematic information. In the case of the Linnaean names it is impossible to restore the original concepts. Short of squarely dismissing them (to us the best alternative, but too late now), the solution is to find an acceptable compromise - which was attempted, without much success, by Klauber (1941 q.v.i.).

Houttuyn (1764), in his adaptation of the Linnaean system, discusses briefly Linnaeus's concept of the genus and embarks on a discussion of the literature. The accounts of North and South American species, and even of supposedly Oriental ones, and especially of their emotional impact, are always treated jointly, as of a single entity. This is an interesting point in the history of Herpetology as a scientific discipline, but is confusing in the present context of assigning names to the South American forms. In this regard Houttuyn faithfully follows Linnaeus: he presents one figure of a rattlesnake (pl. 54: 1), copied from Seba, from the "East Indies", showing no color pattern and numbering some 42 segments to the rattle. It does not seem recognizable.

Linnaeus (1766: 372), in the twelfth edition of the Systema, adds two new species, miliarius (now Sistrurus) and mutus (now Lachesis). As to the species previously described, he adds new citations from Seba and leaves the rest unchanged.

Vosmaer $(1767,1768)$, the curator of the zoological cabinet of Stadholter William V of Holland at The Hague, has a very interesting article that, curiously enough, never attracted proper attention. Besides experiments with the venom, he discusses (1768: 12) six specimens from Surinam
- three of them, he says, depicted by Seba (1735: pl. 45, fig. 4). (Incidentally this, a precise and reliable locality, is unusual for a Seba plate). Vosmaer comments on the Linnaen device of characterizing snake species by counts of ventral and subcaudal scales, and attempts to identify his own specimens by this means. He finds them in agreement with Linnaeus's horridus. This was the beginning of the preKlauberian tradition of applying horridus to South American snakes. This was not such an unreasonable construction, especially given the information on Seba's specimens. Klauber's purely pragmatic proposal (see below) was in fact motivated by the lack of positive data on the Linnaean types and on the strength of North American tradition. Klauber (1956), incidentally, does not cite Vosmaer.

Vosmaer's specimens were certainly taken to Paris with the remainder of the Stadholter's museum, plundered by the French army in 1795 (Pieters 1980); apparently there is no trace left of them. Anyway, as Vosmaer did not innovate in nomenclature, the interest of his paper resides in the early and perceptive attempt to use numerical methods in taxonomy. As to Seba's collections, they were dispersed (Boeseman 1970); some specimens were later tracked (e.g. Thomas 1892), but no rattlesnake.

As a curious and obliquely informative note, Vosmaer (1768: 6) informs that rattlesnakes were called "boicininga" in Surinam. This could hardly be so. The term ("snake that makes noise") is of the Tupí-Guaraní language, which was never spoken in northern South America - not even near Surinam. The citation indicates instead that Vosmaer was acquainted with Piso or Marcgrave, or both, although he does not quote them.

Laurenti (1768) includes in his genus Caudisona (explicitly a new name for Crotalus) five species:

1. Caudisona terrifica, sp.n., based on Seba (II: 95: 1), which had already served as partial basis for Linnaeus's $C$. horridus.

2. C. durissus, a Linnaean name maintained without reference to Linnaeus and based instead on Catesby 
(1731-1743), and so on a North American snake.

3. C. gronovii, sp.n., based on Gronovius's (17541756) Museum Ichthyologicum, p. 45, a citation already used by Linnaeus for $C$. durissus.

4. C. dryinas, for which he literally repeats Linnaeus, including the wrong citation of the Amoenitates Academicae.

5. C. orientalis, based on Seba (II: 96: 1 and II: 95 : 3 ), both citations already used by Linnaeus for $C$. dryinas.

Fermin (1769: 218) was the second author to report on undoubtedly South American Crotalus, in the case also from Surinam. He does not use a Latin name, and repeats the usual comments on the rattle and the poison.

Boddaert (1783: 16), in a paper with an avowed systematic intention, accepts three species of Crotalus: (i) C. horridus L., (ii) C. durissus L. (of which he states having seen one specimen), and (iii) C. exalbidus, a new name for $C$. dryinas, explicitly cited from the Systema Naturae and respective Seba references.

Weigel (1783) repeats Linnaeus and Laurenti.

Daubenton (1784) is an encyclopaedic dictionary. The relevant entries in the present context are: (i) "boiquira" (p. 593), a Marcgrave name, to become important in the literature; (ii) "serpent à sonette"' (p. 678); and (iii) "teuthlaco"' (p. 685), a name from Hernandez (1651), applied to C. durissus, strictly from the literature.

Gmelin (1789: 1080-1081), in his "thirteenth", edition of the Systema Naturae, includes five species of Crotalus, the same as Linnaeus (1766). $\mathrm{He}$ has, however, some changes in the literature he cites: (i) Michaelis (1785) is added to C. horridus: (ii) Laurenti (1768), Boddaert (1783) and Weigel (1783) to the appropriate species, and Vosmaer (1767) to C. durissus. He questions the generic assignment of $C$. mutus.

Of these additions, Michaelis (1785) is no doubt the most interesting. It deals with the subjects of relevance at the time, length and thickness of individual snakes, temperament, venom and bite (especially for us, the search for an antidote) in a professional and level-headed way. Unfortunately, it is all on northeastern North American snakes.

Lacépède (1789: 130, 408 seq.) includes five species of rattlesnakes; the proposed scientific names are given on a "table méthodique" (p. 130), individual treatments later. Given the great homogeneity of the genus, Lacépède describes in detail only the "boiquira", Crotalus boiquira, new name for Linnaeus's $C$. horridus. The distribution is given as extending from the Straits of Magellan (Tierra del Fuego) to Lake Champlain (in the northeastern U.S. near the Canadian border). In accordance with this broad distribution, Lacépède's comments are drawn from a variety of authors, from Marcgrave and Piso, who dealt with northeastern Brasil, through Hernandez on Mexico to Catesby and Kalm, on the United States. Considering the highly heterogeneous quality of Lacépède's information, this new name of his, Crotalus boiquira, could be taken seriously only if the specimen in Paris were extant. It is not (Thireau 1991). In fact, Duméril and Duméril (1851) refer no rattlesnakes in the Paris collection.

Besides (mis-)naming the "boiquira", Lacépède included in Crotalus three Linnaean species, durissus, dryinas and miliarius, and proposed a fully new one, $C$. piscivorus, currently valid in the genus Agkistrodon.

Bonnaterre $(1790 \mathrm{a}, \mathrm{b})$ should be taken in conjunction with Daubenton (1784), to which he adds nothing.

The citation of Andrada (1791) is only a bibliographical curiosity aimed at Brasilians. José Bonifácio de Andrada e Silva, the "patriarch" of Brasilian independence, is known for his scientific activities in the field of mineralogy (Figueiroa 1997). This is the first reference we find to zoological interests. The paper deals superficially with envenomation, and is not relevant, but contains an intriguing phrase, unexplainable to this day: "The author reduces to fewer than 21 the total number of poisonous snakes".

Donndorff (1798), another paraphrase of Linnaeus (in fact of Gmelin, i.e., of the "thirteenth" 
edition), maintains miliarius, horridus, durissus, dryinas and mutus, which latter species he speculates might be a Boa, and cites a wealth of eighteenth century literature, fortunately irrelevant in the present context. He cites, curiously enough, Crotalus piscivorus Lacépède, as "Neuere Gattungen" ("recent genera").

Suckow (1798: 149), as many authors of the time, followed Lacépède, further adding two varieties: one, after Vosmaer (1768), unnamed, to $C$. durissus, and another, $C$. orientalis Laurenti, 1768, to $C$. dryinas.

Latreille $(1801 \mathrm{a}, \mathrm{b})$ has a long chapter on rattlesnakes. He comments on the current confusion and adds to it. After the usual generalities on the rattle and the venom, he treats systematically eight species, of which four are described as new, reportedly with types in the Paris Museum: (i) C. rhombifer (p. 197), no type locality given; (ii) C. immaculatus (p. 201), after a figure of Seba, attributed to the East Indies; (iii) C. simus (p. 202, also after Seba, allegedly from Ceylon; and (iv) C. atricaudatus, from the United States, collected by Bosc. The type locality cited for the latter is "Carolina", accepted by Klauber (1956). If there were interest in further refinement, the locality might be corrected to the neighborhood of Wilmington, North Carolina, where Bosc was for a time French consul (Aulard 1907). In his "additions" at the end of the text Latreille (1801: 313) restricts both C. durissus and C. horridus to North America, based on specimens collected by Ambroise Palisot de Beauvois during his exile in Philadelphia. He removes from Crotalus the species mutus and piscivorus.

Thireau (1991), in his most useful paper on old French rattlesnake types and notable specimens, remarks that he was unable to locate any Latreille specimen. He follows Hoge and Romano-Hoge (1981a, b) in assigning simus to the synonymy of C.d. durissus, and McCranie (1980 - in fact, Schmidt 1953) in assigning rhombifer to that of adamanteus.

Daudin (1802) has a very good survey of eighteenth century literature, and seems to be the first author to state that no species of Crotalus occurs on both Americas. In his volume 5 Daudin (1802: $47-$ 75 ) includes a text by Palisot de Beauvois on North American rattlesnakes, especially on their temperament, on hibernation and on the treatment of bites. His handling of the species, however, is less discerning; for instance, in spite of all the information to the contrary already available, he considers the number of rattle segments a valid systematic character. $\mathrm{He}$ accepts three Linnean species, durissus and miliarius in North America, horridus (the "boiquira") in South America. C. simus and C. rhombifer, both of Latreille, are accepted at face value, and a new name is proposed, $C$. strepitans for $C$. immaculatus Latreille.

Thireau (1991) remarks that there is no extant type of Daudin's strepitans. This is not surprising, since the name was expressly intended as a replacement for immaculatus. Thireau follows Klauber (1972) in assigning this name to the synonymy of C. durissus terrificus, which is in fact meaningless, as Klauber's terrificus is a complex mix.

Bechstein (1802) mixes straight translation of Lacépède into German with updatings. His treatment is in general uncritical: he simply lists, without comment, $C$. boiquira, $C$. dryinas, $C$. durissus, C. miliarius and $C$. piscivorus.

Shaw (1802) accepts four species, three (horridus, durissus and miliarius) from North America, and one, dryinas, from an unspecified American region.

Hermann (1804) describes as new Crotalus tesselatus, no locality, said to differ (no details given) from $C$. horridus in color pattern and number of scales $(151+21)$. Oppel $(1810,1811 \mathrm{a}, \mathrm{b})$ revises the work of earlier authors, and finds Linnaeus's and Laurenti's schemes good at the generic level.

Humboldt (1813) brings the first meaningful contribution to the study of South American rattlers. Two species are described, from the same locality, Cumaná in Venezuela. Crotalus cumanensis and $C$. loeflingii are said to differ in details of color pattern, body shape and tooth shape; they are currently considered synonyms. Humboldt briefly diagnoses the species he considered valid (horridus, 
durissus and rhombifer) on the basis of scale counts and color pattern. In spite of his misapprehensions, Humboldt's paper is the first one that can be called professional, but was overlooked in the literature. Venezuelan rattlesnakes were included in the melting pot of the old names (horridus and durissus) until Boulenger (1896) placed them under terrificus, a position next adopted by Milá de la Roca (1932) and others, explicitly under the influence of Amaral. It was only J.A. Peters (1967) who, in a critique of Roze (1966), re-established cumanensis, which remains valid. Pérez-Santos and Moreno (1988) unexplainably attribute the species to Hoge (1966).

Cuvier (1817) did not aim at completeness in his treatment of genera, just at exemplification. With regard to Crotalus he clarifies ( p. 78) that the name horridus should be applied to a North American species, durissus to a South American one; no further explanation is given. Exactly the same treatment is given in the succeeding editions of the Règne Animal (Cuvier 1829, Duvernoy 1842, GuérinMéneville 1829-1844). The figure in the "disciples" edition is quite convincing for a South American specimen. Schinz (1822) in his translation is faithful to the original.

Goldfuss (1820), as noted in Vanzolini (1977: 23 ) is a mere compilation, without further meaning. The same may be said of Hemprich (1820).

Merrem (1820), is a very important book, but contributes nothing to the issue. He accepts five species: miliarius (from Carolina), durissus (Mexico and South America), atricaudatus (North America), dryinas (North America) and rhombifer ("America"). His only novelty is the synonymy of C. tesselatus Hermann, 1804, with C. rhombifer sensu Daudin, in whose synonymy he also includes

\section{C. horridus $\mathrm{L}$.}

Wied (1821: 170), in his Reise, has the first post-Linnaean mention of a Brasilian rattlesnake. He remarks on meeting the species (which he called C. horridus L.) in Angicos, Bahia, and has brief notes on its ecology and distribution in the open formations of the area. In his additions to the Reise, Wied (1850: 124) mentions a rattlesnake, but only as a pretext to briefly discuss popular beliefs on venomous snakes.

Fleming (1822: 294) keeps Laurenti's genus Caudisona for C. horrida ("boiquira") and Crotalus for C. miliaris ("millet'). His work had no repercussion.

Lichtenstein (1822: 249) comments on Marcgrave's illustration; he uses the name $C$. horridus but does not enter into the systematics.

Schinz (1822), in spite of being, as the title of the book implies, a sequel to Cuvier, contains much additional matter (Vanzolini 1977: 28) - but not on Crotalus.

Bory de Saint-Vincent (1824) summarizes uncritically earlier literature.

Wagler's (1824) contribution, the description of Crotalus cascavella, however, was and for quite some time continued to be, the best. It is comprised of two complementary (non-overlapping) texts, one in French, on rattlesnake generalities, mostly North American, and the other a Latin description of the new form. The latter is terse and to the point. It mentions the shape of the head and of the body scales, and contains a short but quite adequate description of the color pattern. The accompanying plate is excellent - it is a form that can be confidently identified, the first since Linnaeus started the confusion. It is true it has not a definite type locality ("non rarus in campis provinciae Bahiae"), but the ecological connotations and the very explicit itinerary of the expedition (Vanzolini 1981a) that collected the specimen make up for the deficiency. The type has been lost (Hoogmoed and Gruber 1983), but the loss is not serious.

Kaup (1825) immediately after sank C. cascavella ("ist rhombifer Daud".), to which Wagler (in Boie 1827) promptly retorted. However, in his synoptic Natürliches System, Wagler (1830: 176) accepts only two species of rattlesnake, horridus L. (with which he explicitly synonymizes his own cascavella) and atricaudatus, which he attributes to Daudin. No geographic indication is given. Jan (1859: 275) likewise laconically says "Crotalus cascavella = Crotalus horridus". 
Gray (1825) for the first time proposed a separate genus for the rattlesnakes with large regular scutes on the top of the head. He called it Crotalophorus, unfortunately a homonym of Crotalophorus Houttuyn, 1764, itself a strict synonym of Crotalus Linnaeus, 1758. A valid name was proposed only in 1883 (Sistrurus Garman), but the concept was firmly established, and from now on we need not to occupy ourselves with this purely North American entity.

Wied (1825), in the Beiträge, has a very good description of northeastern Brasilian Crotalus, and sensible notes on distribution and systematics. It is not clear, however, on which materials he relied. In his works there is no mention of actual specimens, and there is no rattlesnake in what remains of his collection at the American Museum of Natural History. However, his description is detailed and accurate, and accompanied by obviously original measurements.

Fitzinger (1826 a) lists three species: C. horridus L. ("America, Brasilia"), C. catesbaei Hemprich ("America septentrionali") and Caudisona miliaris (L.) ("America septentrionali'). It should be noted that, although Hemprich (1820: 125) in fact mentions the name catesbaei, he presents no description or identifying citation. In his next paper (Fitzinger, 1826b), he is acidly critical of Wagler (1824): he was apparently very annoyed at a book published in Germany containing texts in French, as well as at the use of Latin, a dead language, in a scientific paper. His conclusion, based on a consideration of scale counts and color pattern, was that three species of rattlesnakes were valid: Crotalus catesbaei Hemprich and Caudisona miliaris (L.) in North America, and Crotalus horridus L. in South America. With the latter he synonymyzed C. cascavella Wagler, $C$. horridus sensu Wied, $C$. dryinas L., C. immaculatus Latreille, C. strepitans Daudin. C. simus Daudin and (in part, no further details) C. durissus L. Such extensive lumping is certainly strange coming from Fitzinger, beyond doubt the most extreme splitter in the history of systematic herpetology. Wagler (1827) replied angrily to the criticism, but did not specifically mention Crotalus.

Friedrich Boie (Boie 1827), under the pretext of commenting on Merrem's system, presented in the Isis von Oken a précis of his brother Heinrich's own classification. With regard to Crotalus, he lists, with practically no comments, miliarius, durissus (cascavella being a synonym), atricaudatus, dryinas and rhombifer, besides two North American species newly described by Say, C. confluentus and C. tergeminus.

Schinz (1835: 164 seq., pl. 74) lists as valid only two species, C. miliarius and C. horridus L., the latter including, as synonyms, C. rhombifer sensu Daudin, C. "tessellatus" Hermann, C. cascavella "Spix", C. atricaudatus sensu Daudin, and, with doubt, $C$. orientalis Laurenti. He also includes in the synonymy vernacular "boiquira" (Marcgrave 1648) and "boicininga" (Piso 1648). He has color plates of the two forms he accepts, with no indication of source. His horridus is certainly not based on a South American specimen; the plate reminds one rather of North American C. horridus.

Schlegel (1837) published two very important books, summarizing his outlook on herpetology and the contents of the rich contemporary Dutch collections. In the Abbildungen (Schlegel 1837-1843), a book with a pronounced Asian bias, he mentions few crotalines and no Crotalus. In the Essay sur la physionomie des serpens he includes (p. 555 seq., pl. $\mathrm{XX}$ ) four species: C. horridus from South America, C. durissus, from North America, C. miliarius and at, this late date, $C$. mutus. The figures are very good-looking, but those of the cephalic scutellation of $C$. horridus and C. durissus do not seem to correspond to current ideas about these forms.

Filippi (1840) has no contribution. The collection he reports upon (Pavia) sounds interesting, as part of it is said to come from Seba's cabinet (loc.cit.: 3 ), but the paper does not mention rattlesnakes.

The “disciples'” edition of Cuvier's Règne Animal (Duvernoy 1842) is, as already said, a faithful reproduction of the previous editions, first and second, and adds nothing. The figure (plate 33: 1) is of a very young specimen. 
Gray (1842) is an attempt at a broad synthesis of an insufficiently known group. Among the thirty species of crotalines he recognizes there are two inclusive ones, containing, among others, the South American species. For present purposes the paper is irrelevant.

Fitzinger (1843), dealing with snakes at the generic level, divides Linnaeus's genus Crotalus in two. For C. miliarius, adequately described by Linnaeus in the $12^{\text {th }}$ edition, but attributed by Fitzinger to himself, he assigns the genus Caudisona, erected by Laurenti (1768) for terrifica. For the remaining species he maintains Crotalus, with three subgenera: Crotalus L., for horridus L., Uropsophus Wagler, for triseriatus Wagler, and Urocrotalon, new, for durissus L. At the time there was not yet a clear distinction between systematics and nomenclature, and Fitzinger signified within a parenthesis (in the case of Crotalus) that Linnaeus had proposed the name but not quite ("non stricte in eodem sensu") the concept.

Tschudi $(1845,1846)$ has the earliest reference to Crotalus in Peru. He follows Schlegel's scheme, using (1846: 17) the name horridus (sensu Daudin) to include horridus sensu Wied and cascavella Wagler; apparently (p. 63) he saw specimens, but his data on distribution ("montañas des nördlichen Theile"') is at variance with current information, which limits Crotalus to southern Peru (see Appendix 1).

Berthold (1846: 25), also an explicit Schlegel follower, cites two species: horridus (Surinam) and durissus (Carolina).

Troschel (1848) has notes, from Richard Schomburgk, on the distribution of Crotalus (horridus, sensu Schlegel) in the Guianan savannas and along the coast. He refers for the first time to the presence of rattlesnakes up to 6000 feet (ca $1800 \mathrm{~m}$ ).

Gray (1849), in the first British Museum snake catalogue, separates Crotalus from Uropsophus by some minor details of head scutellation. He does in both genera a considerable amount of lumping, but, as there is no discussion, the point is irrelevant to us.

Le Conte (1853) discusses two names, horridus and terrificus. He attributes both to North American species; we find his account confusing. He seems to call Crotalus terrificus the southern "Oak Ridge Rattle Snake', the present C. adamanteus. Consequently, $C$. durissus would be the "Pine Barrens Rattle Snake", presently C. h. horridus. Cope (1859) refers favorably to this article by Le Conte. We differ. To get an idea of his competence, one needs only to note that Le Conte (1853: 416) called Laurenti an "illustrious Italian"; the title of Laurenti's Synopsin begins: “Josephi Nicolai Laurenti austriaci viennensis...'. Another curious point in Le Conte's paper, which we haven't seen cited since is (1.c.: 417-418): "The male is generally to be distinguished by a black spot behind the occiput'.

By this time the history of North American rattlers was beginning to be better known (a good summary is in Baird and Girard 1853), but Duméril, Bibron and Duméril (1854), the emblematic Herpetology of the time, still adhered to the scheme of South America horridus and North American durissus, with the addition of rhombifer Latreille as a junior synonym of, yet preferable to, adamanteus Palisot de Beauvois, 1799. This scheme was still used in Paris in 1861 (A. Duméril 1861: 439).

Guichenot (1855), in his report on the herpetological results of Castelnau's expedition to Brasil and Bolivia, mentions one specimen of rattlesnake ("C. horridus"), from "la province de Chiquitos au Pérou". This is a bad anachronism. Chiquitos had always been a part of Bolivia, which in 1776 had been transferred from the viceroyalty of Peru to that of Buenos Aires, and become an independent country in 1825, a fact well known to Castelnau (1851, 1852, 1866), who labeled his maps "Republica de Bolivia'.

Cope (1859) remarks on the prevailing nomenclatural confusion; he adopts Le Conte's (1853) scheme. However, his concept of durissus is broader than Le Conte's, including explicitly one Mexican and one Surinamese specimens. All in all his treatment is quite sensible.

Bates (1864: 295) has the first mention of rattlesnakes in patches of open formations in Amazo- 
nia, specifically in Parintins (then Villa Nova) and Santarém. Unfortunately, he collected no specimens - at least none is mentioned in the British Museum Catalogue (Boulenger 1896: 575).

Cope (1867), commenting on a large collection from Arizona, has a key to the genus Caudisona, which to him included all rattlers, with the exception of the species now in Sistrurus, and of Crotalus lepidus, for which he erected the new genus Aploaspis. The two main characters Cope used in rattlesnake systematics were the scalation of the top of the snout and the shape of the rattle (acuminate vs parallelogrammic). Cope (1884) himself corrected the name to Haploaspis. Two other generic names had been proposed for North American Crotalus, but not generally adopted: Crotalinus Rafinesque, 1818 (type cyanurus $=$ horridus) and Aechmophrys Coues, 1875 (type cerastes).

Jan and Sordelli (1874) present excellent plates of specimens with approximate localities. According to then prevailing ideas, their durissus is no doubt North American horridus; their plate of horridus (livraison 46, plate 3, fig. 1) is the best rendition of South American durissus so far.

W. Peters (1877: 459) uses C. durissus for a Venezuelan (Calabozo, estado Guárico) rattlesnake. So does Ernst (1877) referring to Venezuela in general.

Garman (1883), in a paper that started as a list of the snakes of Kentucky and ended by comprising all of America north of Tehuantepec, cites durissus as extending from Brasil to Mexico. He proposes, without calling attention to the novelty, the new genus Sistrurus, including catenatus (plus one variety) and miliarius (plus two varieties).

Lacerda (1884) is the first Brasilian zoologist to write on rattlesnakes; he uses the name horridus. It is interesting to note that he remarked on the abundance of rattlers in Marajó and Roraima (then Rio Branco); this went unnoticed for a long time.

Cope (1887: 59) has a short but extremely important paper on Crotalus from Chapada dos Guimarães, north of Cuiabá. He synonymizes C. cascavella Wagler with $C$. terrificus Laurenti, and de- scribes its color pattern as: "a brown snake with brown dorsal rhombs with narrow yellowish borders", in which it would differ from C. durissus (= C. horridus sensu Duméril and Bibron), a "yellow snake with brown dorsal rhombs which have yellow centers, the brown being little more than a border'. (It will be remembered that $C$. horridus was the name preferred by Duméril and Bibron for the South American rattlesnakes in general). Cope was the first to make a meaningful, accurate and sensible statement about rattlesnake color pattern; this in 1887.

Lidth de Jeude (1887) described, from the Dutch Caribbean island of Aruba, Crotalus horridus var. unicolor, later to become the focus of much discussion.

Cope (1892: 694) firmly established durissus in South America and distinguished between it and terrificus in a good key (p. 688). Cope (1895) has the first figure of the hemipenis of a South American specimen.

Boulenger, in his Catalogue (1896: 572 seq.) deviates from the usual high level of his syntheses. He was, in fact, frequently inexperienced on North American snakes (Battersby 1971), and this is quite evident in his treatment of Crotalus. He lumps under terrificus (and in this he was much followed) such disparate forms as basiliscus and molossus; on the other hand, he presciently subdivides terrificus in two varieties, with and without neck stripes, anticipating Amaral's (1926a, b, c, d) varieties and the present subspecies.

Ditmars (1905) described from Guatemala another form, C. pulvis, remarkable for being patternless. This was also fated to be the focus of controversy; we will return to it when discussing albinism.

Mocquard (1909) in the Mission Scientifique au Mexique, places (as everybody did, following Cope) durissus and terrificus next to each other. His geography, however, is fanciful: both forms would reach Arizona, New Mexico and Texas to the north.

Vital Brazil (Brazil 1911, 1914) inaugurates the era of Instituto Butantan publishing on Brasilian snakes. He uses the name terrificus, and has no 
zoological contribution.

Rodolpho von Ihering (1911), then at the Museu Paulista (now Museu de Zoologia, Universidade de São Paulo), published a semi-popular work on the snakes of Brasil: he also adopts the name terrificus and describes the color pattern of specimens from the state of S. Paulo.

Ducke (1913) has definite data on the occurrence of rattlesnakes in disjunct spots of open vegetation ("campos") in Amazonia.

Werner (1922), who explicitly followed Cope, also grouped together in a key durissus and terrificus, as having on top of the snout three pairs of scutes meeting on the midline, four scale rows (the circumorbital circles included) between the eye and the lip, and cervical stripes. They would differ in color pattern, though, durissus being yellow, with yellow-centered dark dorsal rhombs, terrificus brown, with darker, light-edged rhombs. This is precisely Cope's (1887) scheme. In the list that follows the key Werner gives scale counts and measurements for terrificus; durissus is unfortunately (if characteristically) omitted.

Amaral (1926c), in reference to chromatic variation in Brasilian snakes, proposes two varieties of Crotalus terrificus: (i) collirhombeatus, with a design of irregular rhombs on the neck, and (ii) collilineatus, with longitudinal cervical stripes. He took no nomenclatural steps: he neither designated hypodigms, nor type localities, nor even mentioned individual specimens. He gave only broad geographical data on the distribution of the varieties: collirhombeatus had so far been found in the Brasilian states of Piauí, Ceará and part of Bahia, while collilineatus had been found in the "central and Southern-oriental parts of the country', namely the states of Minas Gerais, Rio de Janeiro, S. Paulo, Mato Grosso, Paraná and Rio Grande do Sul, as well as, probably, in Argentina and Paraguay. Later, Hoge (1966) proposed that collilineatus be considered a subspecies of $C$. durissus, designating a lectotype from "the state of Mato Grosso". The other variety, collirhombeatus, would also be a subspecies of durissus, but a junior synonym of cascavella Wa- gler. We shall return to this question.

The International Commission on Zoological Nomenclature (henceforth ICZN, 1926: 3) placed (Opinion 92), Crotalus L., 1758, type horridus L., 1758 , together with eight other genera of reptiles, in the Official List of Generic Names.

Amaral's next paper (1929a, b) is an awkward one to criticize: it is entirely composed of wild statements and unsupported conclusions. In the text, and in a key to the species of Crotalus, durissus is explicitly called a subspecies of terrificus. In a footnote (p. 5) he says about durissus: "This corresponds to Crotalus durissus specimen $\gamma$ referred to by Linné in Syst. Nat. XIII edit.: ... 1788... and described as a separate species by Cope in 1864 and 1866". The thirteenth edition of the Systema Naturae was published in 1789, not 1788, by Gmelin, not by Linnaeus (who died in 1778). The two papers in which Cope, according to Amaral, would have described $C$. durissus as a separate species, are not on Amaral's (1929a, b) list of references. In a footnote he cites a 1864 paper by Cope (Proceedings of the Academy of Natural Sciences of Philadelphia), in which $C$. durissus is not mentioned. In no other paper by Cope can we find a reference to a description of $C$. durissus as a new species.

Additionally, $C$. durissus, originally described in 1758 , ten years before $C$. terrificus, could not be a subspecies of the latter. Klauber (1936) corrected this mistake. Amaral (1937: 161) did not take kindly to Klauber's correction. In a footnote to the second edition of his checklist of the snakes of Brasil he refers to $C$. durissus as nomenclatorially unavailable and proposes the name Crotalus terrificus copeanus to replace it. Gloyd (1940: 123) included this name in the synonymy of $C$. durissus, and thus conveniently killed it for nomenclatural purposes.

In his next paper Amaral (1938) makes still more extravagant statements. He initially states (p. 221) that the varieties described in 1926, collirhombeatus and collilineatus, were exactly that, color varieties of a subspecies ("race"), Crotalus terrificus terrificus. On the same page, however, he says that, given the difference in color of the 
venoms (respectively yellowish and whitish), correlated with (unspecified) "important chemical differences", the two varieties should be considered as good "physiological species". This well illustrates the syndrome of mental confusion that followed these names from the inception - to continue following them in the future.

Gloyd (1940) is the first treatment with a proper professional outlook. The bibliographical review is careful and lucid, and the descriptions are as good as possible with contemporary resources. All the South American populations continued lumped under the name $C$. durissus terrificus; the data on distribution are, however, precarious.

Klauber (1941) was the decisive paper on the application of Linnaean names to the rattlesnakes recognized in his 1936 scheme. Among the taxa recognized, Klauber selected seven forms, based on geographical accessibility in Linnaeus's time.

Klauber's premises were: (i) that the "scale counts (and sexes) as given by Linnaeus are accurate and were made by the same methods as those used today"; (ii) that the scale counts included in Klauber's samples represented the areas from which Linnaeus's specimens were derived, so that the statistical tests would not be affected by intrasubspecific trends or clines.

The statistical tests used were: (i) for each scale count and modern taxon a value of $t$ (Student's) was calculated for the difference between the Linnaean count and the mean of the respective Klauber sample; (ii) the values of the probabilities for all the tests relating to each modern taxon were combined according to Fisher (1938: § 21.1; 1946: 99).

This procedure is theoretically justifiable, but its discriminatory power is low - especially in the case of rattlesnakes, which show little inter-specific variability in scale counts.

The results of the statistical tests were further examined by Klauber under the light of some additional information contained in the literature references cited by Linnaeus in the Systema Naturae (not, though, in the Amoenitates Academicae).

The final results were:
Linnaeus's $C$. horridus corresponds to $C$. h. horridus sensu Klauber / Linnaeus's $C$. dryinas corresponds to $C$. durissus terrificus / Linnaeus's $C$. durissus corresponds to $C$. $d$. durissus.

This is far from a flawless scheme. Klauber himself called attention to some problems. For instance, dryinas, a name ten years older than terrificus, should have been preferred. It was not (Klauber, 1941: 93) because "dryinas, not having been used for a long time, should be neglected, although we can come nearer to a positive identification of this specimen than either of the others". On the other hand (p. 92), "while the chances seem rather remote that the Linnaean type of horridus could have come from the United States, it may be best to continue the name horridus as the specific name of the timber rattlesnake, for we cannot prove absolutely that such an identification is inaccurate." At best a Scotch verdict.

A further criticism that can be leveled at Klauber's paper refers to the scantiness of his database. His data on North American snakes were probably sufficient, but in the case of South America, where he recognized one single subspecies, $C$. $d$. terrificus, he had (Klauber, 1941: 86) 18 specimens, representing an area (Klauber, 1936: 250, fig. 25) of nearly 14 million square kilometers, where geographical differentiation, if not yet known, could be confidently predicted.

Finally, Klauber (e.g. Klauber, 1948: 1) was not aware that the "Mars" symbol $\left(\bigcirc^{\prime}\right)$ did not mean in the Systema Naturae a male specimen, but, among other things, the presence of poison fangs ("tela"), as explicitly stated by Linnaeus (1758: 195). In the case of sexually dimorphic characters this makes a difference.

In this same paper Klauber (1941) describes a new species of Crotalus of the durissus group, C. vegrandis, from Uracoa (estado Monagas, Venezuela). This is a very distinctive species, but Klauber (loc. cit.: 334) states that "it is entirely possible that this may ultimately prove to be a subspecies of durissus, intergrading through a stunted race that seems to be present on Mt. Roraima.' (Its is hard for us to 
figure how a Central American population would intergrade with a northeastern Venezuelan one in Mt. Roraima).

The Roraima rattlesnake, of whose existence Klauber was apprised (pers. comm.) by his friend C. M. Bogert (American Museum of Natural History), would be later described as $C$. durissus ruruima Hoge, 1966.

In his paper on the application of Linnaean names to North American snakes, Klauber (1948) quietly introduced a novelty in the nomenclature of rattlesnakes. These are not the subject of any part of the paper, but, citing "by example"' (1.c.: 2) Crotalus dryinas (which spelling he had consistently used before), Klauber corrects it, without comment, to dryinus, possibly under the impression that this was better Latin, in conformity with the ICZN (1999). The correction is, in fact, uncalled for. Article 11 (b) (ii) and (iii) legislates that Greek, properly transliterated, is an acceptable language (the same as Algonquian), and Appendix B prescribes, with numerous examples, how to go about the transliteration. Accordingly, Crotalus dryinas is nomenclatorially unimpeachable - as, of course, well realized by Linnaeus, who knew Latin.

Smith and Taylor (1950: 348) restricted the type locality of C. durissus to Jalapa, Veracruz, Mexico. The numerous restrictions of type localities in this paper were made wholesale, without reference to any historical or taxonomic analysis; that of $C$. durissus was adequately criticized by Klauber (1956: 31, footnote 5).

Ruiz (1952) is a first, and somewhat feeble, attempt at discriminating the crotaline genera by means of cranial characters (the maxillo-palatal ensemble). This line of research was very competently resumed by Brattstrom (1964) whose conclusion, in what concerns us here, is in agreement with previous opinion: two taxa (to Brattstom subgenera) should be recognized, Crotalus and Sistrurus.

Hoge (1953: 269), in a paper on albinism in rattlesnakes, took Amaral's side against Klauber in the matter of the specific name of the South American rattler: "Klauber's statement that terrificus is a subspecies of durissus is not accepted by Amaral. We agree with Amaral, especially since Klauber's systematic arrangement would further complicate things, as in a large number of papers on the venom of the South American rattler it has been called terrificus terrificus." (Our translation from the German). In fact, the only difference between the names adopted by Amaral and by Klauber resides in the position of the epithets (terrificus durissus and durissus terrificus), neither of which is suppressed; Hoge's argument seems weak to defend a serious breach of the law of priority. Exactly the same position, based on equally lame arguments, was maintained by Sandner-Montilla $(1983,1985)$.

Gonçalves (1956) published a paper entitled " Crotalus terrificus crotaminicus, biological subspecies'. It deals with the geographical distribution of crotamin, a toxic protein discovered by Gonçalves and Vieira (1950) in the venom of Brasilian Crotalus.

Gonçalves and Vieira (1950) had analyzed pools of venom from "northern, central and southern Brasil." Considering that Brasil extends from $0430 \mathrm{~N}$ to $3345 \mathrm{~S}$ (over $4,000 \mathrm{~km}$ ), it seems to us insufficient geographical specification. It was, nevertheless, an intriguing clue, confirming and extending earlier observations of Vellard (1941, 1943), and Vellard and Huidobro (1941) - and most certainly in need of strenuous pursuance. Gonçalves's (1956) paper offers no better geographical information; three localities are mentioned from which venoms containing crotamin were obtained, Morro Agudo, Franca and Ituverava, but it is not made clear where in Brasil these places were (they are in the state of S. Paulo, see Appendix 1). Of the elements nomenclatorially indispensable to the recognition of a new taxon, none was offered: no specimens are mentioned, much less a hypodigm. It seems clear that the authors had at hand only pools of dried venom; the subspecies proposed has no nomenclatorial status. It is a sign of the low esteem in which systematics is held in Brasil that such a travesty of a scientific paper was published in the Annals of the Brasilian Academy of Sciences.

It is an interesting sidelight that Gonçalves 
(1956: 365) explicitly makes the point that the presence of crotamin was in no way related to the color of the venom, contrary to previous belief and to later findings of Schenberg (1959, 1960). Schenberg repeated Gonçalves's work on a much larger scale (530 snakes), and mapped for the state of S. Paulo localities showing venom containing crotamin only, which he considered to come from "genetically pure" snakes, and not containing the toxin, which he took to come from "hybrid" snakes. Unfortunately Schenberg's papers do not include the primary data; we looked for them, but were informed at Instituto Butantan that upon his death his laboratory had been closed and his materials and notes dispersed and lost.

Barrio (1961) criticized Gonçalves's paper, and came to the very sensible conclusion that there is no reason to erect "biological" subspecies.

Klauber (1956) is the magnum opus, in which he synthesizes his lifelong bibliographic, laboratory and field work on rattlesnakes, "their habits, life histories and influence on mankind." It is understandably more closely and extensively concerned with the North American forms; the information on South America is found in:

1. The checklist (p. 27-51), followed by distribution maps and photographs of live specimens. In accordance with his previous work and to some extent with the availability of materials, Klauber accepts two South American subspecies of durissus, C. d. terrificus (Laurenti, 1768) and C.d. vegrandis Klauber, 1941. He accepts a Panamanian gap between Central American durissus and South American terrificus, and synonymizes both Humboldt's species with the latter. His concept of terrificus is too inclusive; he states, however (p. 32, footnote 5): "I have no doubt that, when sufficient materials become available for study, at least three South American subspecies of durissus (besides vegrandis) will be recognized: C. durissus cumanensis Humboldt, 1833 in the north; $C$. durissus cascavella Wagler, 1824, in the Brasilian "bulge"; and C. durissus terrificus Laurenti, 1768, in the south. These further subdivisions will be useful in venom studies. I did not make these segregations in this book because I was unable to secure sufficient material wherewith to determine accurately either the territorial limits or character distinctions that would be necessary to define the three subspecies".

2. Klauber's (1956: fig. 25) map of the distribution of terrificus is not very good, especially in what concerns Peru and Bolivia.

3. In the key (p. 117), the differences in color pattern among the forms that Klauber recognized are adequately described and represented by excellent photographs.

4. From the South American viewpoint, the weakest part of the book is the "Table of Character Variations" (following p. 124). In it the 14 million square kilometers of South America occupied by Crotalus are subsumed in one line (terrificus), without mention of the number of specimens examined. To us, this voids the scheme of any usefulness.

Allen and Neill (1957) have a very interesting paper on the rattlesnakes of the Guyanan savannas. Their locality was McTurk's Homestead, in the Rupununi. They were informed by local people that there were there two species of rattler, a savanna and a bush one. They give measurements and scale counts of six specimens of the savanna form, and compare it with terrificus sensu Gloyd, not very usefully, as the latter is itself a complex composite.

The savanna form was described as new by Harris and Simmons (1978a), under the name Crotalus durissus trigonicus. It was synonymized by Abuys (1987) with C. durissus dryinus, and later, following a lead of Cunha and Nascimento (1980), with C. durissus ruruima by Rubio (1998). We have examined a paratype (Univ. Florida 16159) and agree with Rubio.

Hoge and Lancini (1962) record for Venezuela C. $d$. terrificus and $C$. $d$. vegrandis, but do not recognize $C . d$. cumanensis. Neither does Lancini (1962) in his list of the snakes of Curupao.

Hoge (1966) is a fundamental article, in which 
several far-reaching decisions are taken, but that throughout lacks clarity and organization. Crotalus durissus L. is accepted as the specific name for the Neotropical rattlesnake. Crotalus vegrandis Klauber, 1941, is re-established at specific status. Four subspecies $(C . d$. durissus L., 1758; $C$. d. culminatus Klauber, 1952; C. d. totonacus Gloyd and Kauffeld, 1940; and C. d. tzabcan Klauber, 1952) are confined to Mexico and Central America and will be not further mentioned here. As to the South American forms:

C. d. cascavella Wagler, 1824. A neotype is designated, Instituto Butantan (IB) 23400 from Mina Caraíba, Bahia, Brasil, "near Spix itinerary". The coordinates are 0950, 3952, in fact near the route of the Spix-Martius expedition (Vanzolini 1981a). At the time (1966) the designation of a neotype was not necessary, as there were yet no news of the disappearance of Wagler's type, which became known through Hoogmoed and Gruber (1983). The plate (Hoge 1966: pl. 12) illustrating the neotype disagrees with Wagler's original one, which shows definite diamonds on the cervical region, while the figure of the neotype has longitudinal stripes.

Hoge (1. c.) places C. terrificus collirhombeatus Amaral, 1926, in the synonymy of cascavella. This would need a consideration of nomenclatural aspects, but these are best left for the next subspecies.

C. d. collilineatus "Amaral, 1926". Hoge (1966: 139) says: "Since Amaral's concept of collilineatus includes at least two subspecies, a type specimen must be selected in accordance with international rules of nomenclature between the three ones figured in Amaral's description. By present selection, in agreement with Dr. A. do Amaral, we select IBH $n^{\circ} 2180$, from State Mato Grosso as lectotype of Crotalus durissus collilineatus Amaral".

Although the specimens listed by Amaral (1926) were not explicitly and formally designated as syntypes, they may be reasonably taken to be so under the Code (ICZN, 1999), and become eligible for choice as a lectotype (Art. 72.i.i).

The next point to consider is the elevation to subspecific rank of names originally proposed as infrasubspecific varieties. The Code permits such an elevation, of course under some stipulations. First comes the matter of availability under Art. 45.6.4.1: in the present case, the names were explicitly proposed as varieties, and were used in 1966 (before 1985) as the valid names of subspecies, and thus fulfil the requirements.

As to authorship, Art. 10.2 prescribes that "if an author uses a name previously published at infrasubspecific rank, in a way that makes it available for a species or subspecies, that author thereby establishes it as a new name and it takes his or her authorship Art. 45.5.1 (see also Articles 23.3.4 and 50.3.1)',

Finally, as to date of priority, Art. 23.3.4 prescribes "The Principle of Priority does not apply to names applied to infrasubspecific entities... If a new name which had been published for an entity later established for a species or subspecies (see Articles 10.2, 45.5 and 45.6), then the Principle of priority applies from the date the name becomes available as a result of that establishment'.

All this leads to the conclusion that Crotalus durissus collilineatus Hoge, 1966, and Crotalus durissus collirhombeatus Hoge, 1966, are nomenclatorially valid subspecies.

Hoge's (1966) treatment of the systematics of C. durissus is uneven and highly unsatisfactory from several viewpoints. In a later section we shall deal with the characterization of the subspecies. Here we begin by saying that geographical distributions are too summarily treated, and that there is practically no mention of intergradation, of course a fundamental feature of subspecific variation.

For cascavella very little information is given (not even the sex of the neotype). The geographic distribution is cited incorrectly as "the dry "caatinga' areas of States Maranhão, Ceará, Piauí, Pernambuco, Alagoas, Rio Grande do Norte and Bahia': there are no caatingas in Maranhão; they prevail in the other states mentioned, but rattlesnakes are by no means limited to them; they occur in all open formations. 
Another point concerns the chosen type locality of collilineatus. It is vague, "state Mato Grosso", at the time with an area of over 1.2 million square kilometers. For a subspecies (geographical race) it seems too much imprecision.

There are further questions yet to be raised. About Crotalus durissus terrificus, Hoge (1966: 147) says: "We retain the name of terrificus for the extreme Southern population for following reasons: 1) This population fits best Crotalus durissus terrificus "sensu" Klauber 1956. 2) Most of medical and biochemical research on South American Rattlers was done with venoms from the South, and always terrificus was associated with this research, used either as a specific or subspecific name.' He proceeds to designate IB 22997, from "Julio Castilho, Município Taquarí, State Rio Grande do Sul” as neotype. There are two mistakes here. The actual spelling is "Julio de Castilhos", coordinates 2919, 5340. This locality is the seat of its own municipio; the municipio of Taquarí $(2948,5151)$ is almost 200 kilometers away (Lema 1994: 28).

Several remarks must be made about Hoge's course. First, it would seem preferable to have fitted the solution to Laurenti's original concept, rather than to Klauber's - which was later, nomenclatorially not binding, taxonomically imprecise and in fact never justified or defended, but simply presumed. Second, it cannot be said that "most of" medical or biochemical research was done on Rio Grande do Sul snakes. The bulk of the materials used in such research was in fact from S. Paulo, but geographical origin was never taken into account, not even routinely recorded. Specimens were taken from the communal snake pit, and venoms pooled.

It might also be inquired what the probability was of Laurenti referring, however obliquely, to a Rio Grande do Sul snake. His description is explicitly based on a figure from Seba's collection, whose localities are well known to be fanciful - but see remark on Vosmaer (1768) above - but decidedly do not include southern Brasil. In fact it is highly doubtful that any specimens from Rio Grande do Sul had reached Europe before 1800. By that time 42 South American nominal species of serpents had been described by five authors: Linnaeus (31), Laurenti (6), Sentzen (2), Scopoli (2) and Lacépède (1); not one was listed as from Rio Grande do Sul. Of these, five are presently known to occur in the state, but are so widely distributed in South America and so abundant everywhere that nothing can be guessed about a putative type locality: Boa constrictor, Liophis miliaris, Philodryas viridissimus, Tantilla melanocephala, and Crotalus terrificus. The six species described by Laurenti were Caudisona terrifica, Siphlophis cervinus and four synonyms of Boa constrictor: Constrictor rex serpentum, C. aruspex, C. formosissimum and C. diviniloquus. There is nothing here pointing at Rio Grande do Sul; S. cervinus does not even occur there.

Crotalus dryinas Linnaeus, 1758, unnecessarily, as said, emended to dryinus, and left out of the scheme by Klauber (1956), was revived by Hoge (1966: 142) as subspecies dryinus of durissus L.

In spite of its material flaws, Hoge's (1966) paper should not be prima facie dismissed. Butantan herpetologists handle literally thousands of live snakes, and this certainly educates the eye to significant peculiarities of color pattern that, in the finished research, may turn out to be poorly expressed or even omitted, but are nonetheless real. The case of the varieties/subspecies collilineatus and collirhombeatus is typical. It is obviously indispensable to perform on South American Crotalus a proper analysis of geographical differentiation, starting with color pattern.

This paper by Hoge was the last conceptual contribution to the understanding of the systematics of South American Crotalus. Subsequent authors adopted the scheme; differences are to be noted only on the characterization of the subspecies, which is one of our next themes.

\section{Characterization of the Subspecies}

In the 1966 paper Hoge considers seven South American subspecies, cascavella, collilineatus, cumanensis, dryinus, marajoensis, ruruima and terrificus. His data on the morphological characters (color pat- 
tern and scale counts) are unevenly dispersed among the individual topics. Three subspecies, the two new ones, ruruima and marajoensis, and terrificus, of which, as said, a neotype is designated, are formally diagnosed and described. The meristic characters of those are cited as ranges for the sexes, without indication of the size of the samples; in the case of the new forms that is presumably that of the hypodigms. In the case of terrificus it is impossible to guess, but, given the large number of localities represented on the maps, a sizable sample must have been available. Color patterns are described only for the new subspecies, without mention of variation; it is probable that they are modal accounts. There are brief pairwise comparisons of collilineatus vs. cascavella, terrificus and dryinus vs. durissus, and marajoensis and ruruima vs. terrificus. The plates, which include all forms, are not adequate substitutes for good descriptions, but to some extent they clarify the abbreviated differential diagnoses. All in all, Hoge's treatment does not allow for unambiguous identification of the subspecies. This is not helped by the summary geographical treatment.

The accounts of distributions are indeed very sketchy: instead, there are maps for all subspecies. The localities are not identified on the maps, and it is impossible to retrieve from them the coordinates. This is particularly unfortunate in the case of Map VIII, which is said to include intergradation between cascavella and terrificus. As mentioned, it is not possible to retrieve coordinates from the maps, but a consideration of state borders as depicted places the "intergrade" localities some $750 \mathrm{~km}$ to the north of the nearest terrificus locality. There is no geographical support for Hoge's scheme.

The best representation of the Butantan concepts of rattlesnake subspecies is to be found in Grantsau (1991), who has outstanding paintings and photographs of $C$. d. cascavella, collilineatus and terrificus.

Peters and Orejas-Miranda (1970: v, 74-75; see 1986) present a key to the forms of Crotalus that occur south of the Mexico-Guatemala border and give it a four star (maximum) rating for reliability. In fact, the key is entirely based on Hoge (1966) and, in spite of being more systematically constructed and more clearly written, suffers from the same flaws as its model.

Harris and Simmons (1972a, b) present a combination of Hoge (1966) and Peters and OrejasMiranda (1970; see 1986); they bring no novelties. Hoge and Romano (1973) is again based on Peters and Orejas-Miranda, with figures from Hoge (1966), the latter poorly reproduced. The same scheme is used by Hoge and Romano-Hoge (1981a, b) for the five subspecies they recognize in Brasil, including trigonicus Harris and Simmons, 1978, that they consider might occur in Roraima.

Finally, McCranie (1993) sums up the available literature. With regard to color pattern he also follows Peters and Orejas-Miranda. He is the first author to systematically present scale counts for all the forms recognized (those in Hoge, 1966), but he calls attention to the fact that, being culled from a very uneven literature, these should be taken with caution. His map is also a distillation from the literature, likewise to be taken with caution. This closes this part of the survey. It is fair to say that no clear scheme exists of the geographical differentiation of C. durissus in South America. No significant addition has so far been made to Hoge's 1966 scheme, which, as discussed, is rather superficial and immethodical.

\section{Recently Described SPECies}

After Hoge (1966), two species of rattlesnakes were described, both from Venezuela.

Crotalus pifanorum Sandner-Montilla, 1980, from southern Guárico, was said to differ from cumanensis principally in dorsal pattern: comparative drawings are presented, but are very crude. Differences in scale counts are mentioned but not specified. Lancini and Kornacker (1989: 295) found the species' status "debatable" until more specimens became available. Campbell and Lamar (1989: 344) thought it could not be distinguished at the time, and tentatively considered it a synonym of cumanensis or an intergrade (with what they did not spec- 
ify). However, in an undergraduate thesis, PerezBidó (1992) compared pifanorum and cumanensis as to karyotype, protein electrophoresis and microdermatoglyphics, and concluded that they were good species. This thesis was later formally published (Perez, Rada de M. and Bello de L. 1997): in neither version is there mention of the number or geographical provenance of the specimens compared, but the data seem substantial enough. A good formal treatment of this form seems highly desirable.

Crotalus maricelae Garcia-Pérez, 1995, was described from the Andes of Mérida. It was diagnosed with basis on a character of cephalic scutellation (4-5 prefrontals) and on color pattern. McDiarmid, Campbell and Touré (1999: 283) say that it is a synonym, but do not elaborate the point.

\section{A NOTE ON CHROMATISM}

Deviant color patterns, often called " aberrations", are fairly frequent in snakes. In Crotalus by far the most common deviation, one that has taken taxonomic relevance, is albinism, on which there is a sizable literature, especially on the North American species (Gloyd 1935a, 1958, Hensley 1959, Nickerson and Mays 1968, Klauber 1972, Gilboa and Dowling 1974, Dyrkacz 1981). On the South American forms there is also abundant information (Amaral 1926 b, 1926 c, 1933a, Prado and Barros 1940, 1941, Renault and Schreiber 1951, Hoge 1953c, Miranda, Tio-Vallejo and Grisolia 1985, Bérnils, Moura-Leite and Ajuz 1990, Sazima and DiBernardo 1992).

Albinism in such cases is due to a lossof-function mutation of the tyrosinase gene and exhibits considerable phenotypic heterogeneity (Bechtel 1978, Gilbert 2000). In fact, the literature shows that pure albinos are relatively rare, some kind of a "ghost pattern" of dorsal rhombs over a gray background being predominantly found. This has led some authors (e.g. Klauber, Ditmars), unaware of the genetic aspects of the problem, to deny that such shadowy specimens were albinos; for them only complete ("pure") albinos would count. The tail is frequently, but not always, darker than the body. Albino snakes are found of diverse sizes, and presumably ages, tending to support Sazima and DiBernardo's (1992) contention that predation on nocturnal albinos should not be too severe.

The first mention of an albinistic rattlesnake is by van Lidth de Jeude (1887: 133). In a collection of reptiles from Aruba, Netherlands Antilles, he found one rattler with "no streaks behind the eye, nor any marking whatever. It is on the back of a uniform gray color, somewhat lighter on the ventrals; the very short tail is darker than the body, and its lower part of a bluish black color.' The specimen was made the type of a new variety, unicolor, of Crotalus horridus, as said a current name for the South American rattler in the nineteenth century. A further specimen (no locality) in the Leiden collection fully agreed with the Aruba snake in color and scutellation. Two additional Aruba specimens, kept alive in the Zoo, are also mentioned: one in full agreement with the type, the other showing "on the back a trace of lozenge-shaped spots." The word "albino" is nowhere mentioned.

Meek (1910), commenting on a collection from the Leeward islands, records, without comment, one Crotalus terrificus from Aruba. The specimen is in the Field Museum; we have inquired, and it is ordinary unicolor.

Ditmars (1905) described a new species from Nicaragua, Crotalus pulvis. The type measured 635 $+55 \mathrm{~mm}$; the dorsal background was bluish-gray ("pumice stone") and there was practically no pattern. However, after shedding, a patter of indistinct diamonds could be seen. Ditmars (1.c.) states explicitly that "the possibility of albinism... has been fully considered, and is believed to have no bearing upon the case".

Amaral (1926a: 8), in a paper on chromatism of coral snakes, states, without comment, that $C$. pulvis was a synonym of $C$. terrificus. In a following paper (Amaral, 1926b), on albinism in rattlesnakes, Amaral confirms his opinion and gives a description and a (bad) photograph of the type of pulvis.

The matter was retaken by Gloyd (1936), who 
states that the two forms are "not true albinos". He declared unicolor a good species and pulvis a straight synonym - in spite of the geographical incongruity, which he noted and for which he proposed a rather naive hypothesis (an analogy with the distribution of a Leptodeira).

Hoge (1966), who accepted Gloyd's proposition, tried to solve the geographical problem by supposing the locality of pulvis to be in error. This is a gratuitous supposition. As said, albinos are not uncommon among rattlesnakes, at least another specimen being known from Nicaragua (Villa and Rivas, 1971).

Kauffeld and Gloyd (1939) stressed again that " The possibility that the Aruba specimens are aberrant durissus no longer seems plausible." The exact meaning of "aberrant durissus" is not discussed.

Amaral (1944) emphasized the lack of pholidotic differential characters between unicolor and continental terrificus, and concluded that "the representatives of terrificus in the island of Aruba (coast of Venezuela) would represent a "population" with a tendency to melanism and perhaps to dwarfism, soon to become extinct'".

Klauber (1972: 200) finally states that "it is generally agreed that albinism has little or no effect on evolution; light-colored species are not derived from an albino ancestry. Thus, the Aruba rattlesnake (C. unicolor), a conspicuously light species allied to the Neotropical rattlesnake (C. durissus) is in no way a result of albinism".

The matter seems to us rather simple. The Aruba population has a fixed allele for albinism; it is prevented by its insular situation from intergrading (exchanging genes) with adjacent populations. There is good reason to consider it a good species. The type of C. pulvis is beyond doubt an albino C.d. durissus.

\section{LOCALITIES}

Published information on geographical distribution can be of two sorts: specific, i.e., referring to definite individual localities, that can be reasonably rep- resented by geographical coordinates with little uncertainty, and generic, referring to a country, to a major subdivision (state, province or department) or still to a given ecological or political sub-unit of such a subdivision.

During the preparation of this bibliography several facts early became evident regarding the raw materials for distributional analyses. In spite of the widespread preoccupation with subspecies, there are very few geographically oriented surveys; country and regional lists seldom include specific localities and still more rarely proper documentation. On the other hand, precise indications are often found in non-taxonomic papers (notes on ecology, venoms, chromatism, teratology, and such). Since our aim was to revise as much as possible of the total South American literature, regardless of intention of ulterior publication, we thought it useful to prepare a list of documented localities (Appendix 1). In the literature, they are usually not accompanied by geographical coordinates: those we supply ourselves, and acknowledge the responsibility. Our main source are the gazetteers for individual countries issued by the U.S. Central Intelligence Agency (CIA) under the nom-de-plume "U.S. Board on Geographical Names" and published by the Office of Geography, Department of the Interior. Failing this most reliable and thorough source, it becomes a matter of consulting scattered and frequently obscure literature and, as a last resort, of inconveniencing colleagues unlucky enough to be in the proper country, or collection. A sizable proportion of published South American localities needed extra investigation; we do not include the search details in this paper, but of course our files are open to colleagues.

Accessorily (Appendix 2) we present a list of the generic localities found in the literature.

\section{ACKNOWLEDGMENTS}

There is no need to stress the difficulties met in assembling this bibliography, which spans over three hundred years and involves faunas outside the ordinary scope of South American herpetology. Our first 
thanks are due (as they often are) to Dione Seripierri and her staff at the library of the Museu de Zoologia. Along the same lines we have received invaluable help from colleagues and librarians at many institutions, especially the National Museum of Natural History, Washington, D.C., the American Museum of Natural History, New York, and Georg Augustus Universität, Göttingen. We are also indebted to Ilya S. Darevsky, Russian Academy of Sciences, St. Petersburg. We also wish to stress the invaluable work of the Academy's editorial staff.

Interpretation of Linnaean Latin texts was made possible by the collaboration of Drs. Dan H. Nicolson, National Museum of Natural History, and Haiganuch Sarian and José Eduardo Lohner, Universidade de S. Paulo. Debra Moskovits, Field Museum of Natural History, kindly checked the Meek Aruban specimen published as terrificus.

The task of identifying troublesome localities was much helped by Drs. James Hanken and José Rosado, Museum of Comparative Zoology, Mercedes Foster, National Museum of Natural History, Ignacio de la Riva, Museo Nacional, Madrid, Esteban O. Lavilla, Fundación Miguel Lillo, Tucumán, Federico Achaval, Universidad Nacional del Uruguay, Greg Schneider, University of Michigan Museum of Zoology, and Ned Gilmore, Academy of Natural Sciences of Philadelphia.
Dr Maria de Fátima Domingues Furtado, Laboratório de Herpetologia, Instituto Butantan, lent support to the project at all stages.

Dr. F. Wayne King, University of Florida, loaned the paratype of Crotalus durissus trigonicus.

Finally, C.W. Myers, American Museum of Natural History, and W. Ronald Heyer, National Museum of Natural History, helped at all stages and kindly and very profitably reviewed the manuscript. This work was not funded by any granting agency.

\section{RESUMO}

Fez-se um levantamento da literatura taxonômica sobre cascavéis sul americanas (gênero Crotalus, família Viperidae). Duas áreas mereceram especial atenção: a atribuição dos nomes propostos no século XVIII por Lineu e Laurenti, e o esquema correntemente adotado de diferenciação subespecífica.

A atribuição de nomes é examinada com base nas descrições originais e na literatura anterior e contemporânea relevante. O esquema atualmente adotado, proposto inicialmente por Klauber $(1941,1972)$ é considerado não inteiramente satisfatório, mas suficientemente razoável, além de consagrado pelo uso.

O esquema de diferenciação geográfica, importante em si mesmo e por suas consequiências práticas (diferenciação geográfica do veneno) é considerado como a culminação de uma longa série de análises deficientes, e em urgente necessidade de investigação adequada.

Palavras-chave: Crotalus durissus, Viperidae, diferenciação geográfica, diferenciação do veneno. 


\section{APPENDIX I}

South American localities of Crotalus.

\begin{tabular}{|c|c|c|}
\hline Locality & Coordinates & Authority \\
\hline \multicolumn{3}{|l|}{ COLOMBIA } \\
\hline \multicolumn{3}{|l|}{ Atlantico } \\
\hline Barranquilla & $1100 \mathrm{~N}, 7449$ & Nicéforo 1942 \\
\hline Km 6 Barranquilla - Puerto Colombia & $1100 \mathrm{~N}, 7452$ & Dugand 1975 \\
\hline \multicolumn{2}{|l|}{ Cesar } & Gloyd 1940 \\
\hline Bolivar & $1021 \mathrm{~N}, 7409$ & Ruthven 1922 \\
\hline San Sebastian (de Rábago) & $1034 \mathrm{~N}, 7336$ & $\begin{array}{l}\text { Ruthven } 1922 \text {, Gloyd } 1940^{3} \text {, } \\
\text { Nicéforo } 1942\end{array}$ \\
\hline \multicolumn{3}{|l|}{ Cundinamarca } \\
\hline \multicolumn{3}{|l|}{ La Guajira } \\
\hline \multicolumn{3}{|l|}{ Magdalena } \\
\hline Bonda & $1114 \mathrm{~N}, 7408$ & Griffin 1916 \\
\hline Cacagualito & $1115 \mathrm{~N}, 7352$ & Griffin 1916, Gloyd 1940, Nicéforo 1942 \\
\hline \multicolumn{3}{|l|}{ Meta } \\
\hline $\begin{array}{c}\text { Villavicencio } \\
\text { Tolima }\end{array}$ & 0409 N, 7337 & Nicéforo 1930, 1933, 1942 \\
\hline \multicolumn{3}{|l|}{ Valle del Cauca } \\
\hline Tenerife & $0344 \mathrm{~N}, 7607$ & Nicéforo 1942 \\
\hline \multicolumn{3}{|l|}{ VENEZUELA } \\
\hline $\begin{array}{c}\text { Aragua } \\
\text { Las Mercedes } \\
\text { Bolivar }\end{array}$ & $1008 \mathrm{~N}, 6714$ & Marcuzzi 1950, Roze 1966 \\
\hline Arabupu & $0506 \mathrm{~N}, 6044$ & Roze 1966 \\
\hline Cerro Cariman Paru & $0429 \mathrm{~N}, 6109$ & $\begin{array}{l}\text { Hoge \& Romano 1969, } \\
\text { Hoge \& Romano-Hoge 1981a,b }\end{array}$ \\
\hline Cuquenan & $0511 \mathrm{~N}, 6049$ & Roze 1966 \\
\hline Danto Manchado camp 1 & $0724 \mathrm{~N}, 6254$ & Gorzula \& Señaris 1998 \\
\hline camp 2 & $0724 \mathrm{~N}, 6254$ & Gorzula \& Señaris 1998 \\
\hline El Diamante & $0716 \mathrm{~N}, 6227$ & Gorzula \& Señaris 1998 \\
\hline El Manteco & $0727 \mathrm{~N}, 6232$ & Gorzula \& Señaris 1998 \\
\hline Hato El Paraiso & $0731 \mathrm{~N}, 6231$ & Gorzula \& Señaris 1998 \\
\hline Hato Kamariapo & $0720 \mathrm{~N}, 6226$ & Gorzula \& Señaris 1998 \\
\hline
\end{tabular}




\section{APPENDIX I ( continuation )}

\begin{tabular}{|c|c|c|}
\hline Locality & Coordinates & Authority \\
\hline Hato La Vergareña & $0650 \mathrm{~N}, 6334$ & Gorzula \& Señaris 1998 \\
\hline Parupa & $0531 \mathrm{~N}, 6337$ & Gorzula \& Señaris 1998 \\
\hline Paulo & $0506 \mathrm{~N}, 6048$ & Gloyd 1940, Hoge 1966, Roze 1966 \\
\hline Hato Terekay & $0729 \mathrm{~N}, 6232$ & Gorzula \& Señaris 1998 \\
\hline Upata & $0801 \mathrm{~N}, 6224$ & Gorzula \& Señaris 1998 \\
\hline \multicolumn{3}{|l|}{ Carabobo } \\
\hline \multicolumn{2}{|l|}{ Distrito Federal } & Roze 1952, Hoge 1966 \\
\hline Baruta & $1026 \mathrm{~N}, 6653$ & Alemán 1952 \\
\hline Camuri Chico & $1037 \mathrm{~N}, 6652$ & Roze 1953,1966 \\
\hline Caracas & $1030 \mathrm{~N}, 6655$ & Boettger 1898, Roze 1966, Tello 1968 \\
\hline Catia La Mar & $1036 \mathrm{~N}, 6702$ & Roze 1966 \\
\hline El Cementerio & $1039 \mathrm{~N}, 6656$ & Marcuzzi 1950, Roze 1966 \\
\hline El Junquito & $1028 \mathrm{~N}, 6705$ & Marcuzzi 1950, Roze 1966 \\
\hline El Valle & $1027 \mathrm{~N}, 6655$ & Marcuzzi 1950, Roze 1966 \\
\hline Macanao & $1026 \mathrm{~N}, 6702$ & Marcuzzi 1950 \\
\hline Tacagua & $1032 \mathrm{~N}, 6659$ & Roze 1966 \\
\hline \multicolumn{3}{|l|}{ Falcón } \\
\hline Pauji & 1049 N, 6936 & Shreve 1947 \\
\hline Riecito & $1055 \mathrm{~N}, 6844$ & Shreve 1947, Roze 1966 \\
\hline $\begin{array}{c}\text { Cerro Santa Ana } \\
\text { Guárico }\end{array}$ & Guárico & Bisbal 1990 \\
\hline Calabozo & $0856 \mathrm{~N}, 6726$ & Peters 1877 \\
\hline Espino & $0834 \mathrm{~N}, 6601$ & Marcuzzi 1950, Roze 1966 \\
\hline San Juan de Paya & $0932 \mathrm{~N}, 6714$ & Roze 1966 \\
\hline $\begin{array}{l}\text { type locality of C. pifanorum } \\
\text { Lara }\end{array}$ & $0759 \mathrm{~N}, 6544$ & Sandner-Montilla 1980 \\
\hline \multicolumn{3}{|l|}{ Merida } \\
\hline Egido & $0833 \mathrm{~N}, 7114$ & Vellard 1941 \\
\hline $\begin{array}{l}\text { Muchachay } \\
\text { Miranda }\end{array}$ & Miranda & Garcia-Perez 1995 \\
\hline Curupao & 1030 N, 6639 & Lancini 1962 \\
\hline Las Mercedes & $1026 \mathrm{~N}, 6653$ & Marcuzzi 1950 \\
\hline Ocumare del Tuy & $1007 \mathrm{~N}, 6646$ & Roze 1966 \\
\hline Pico Naiguatá & 1033 N, 6646 & Gloyd 1940 \\
\hline Santa Lucia & $1018 \mathrm{~N}, 6640$ & Gloyd 1940, Marcuzzi 1950 \\
\hline Turgua & $1023 \mathrm{~N}, 6646$ & Marcuzzi 1950 \\
\hline \multicolumn{3}{|l|}{ Monagas } \\
\hline Caripito & 1007 N, 6303 & Beebe 1946 \\
\hline San Antonio de Maturin & $1007 \mathrm{~N}, 6343$ & Gloyd 1940 \\
\hline \multicolumn{3}{|l|}{ Sucre } \\
\hline Laguna Campoma & $1031 \mathrm{~N}, 6326$ & Roze 1966 \\
\hline Puerto de Hierro & $1038 \mathrm{~N}, 6205$ & Roze 1966 \\
\hline Tunapuy & $1034 \mathrm{~N}, 6307$ & Gorzula \& Señaris 1998 \\
\hline
\end{tabular}




\section{APPENDIX I ( continuation )}

\begin{tabular}{|c|c|c|}
\hline Locality & Coordinates & Authority \\
\hline \multicolumn{3}{|l|}{ Trujillo } \\
\hline Rio Burbusay & $0931 \mathrm{~N}, 7016$ & Vellard 1941 \\
\hline Carache & $0938 \mathrm{~N}, 7014$ & Garcia-Perez 1995 \\
\hline \multicolumn{3}{|l|}{ Zulia } \\
\hline Maracaibo & 1040 N, 7137 & F. Müller 1892 \\
\hline Lower Rio Negro & $0935 \mathrm{~N}, 7212$ & Alemán 1953 \\
\hline \multicolumn{3}{|l|}{ GUYANA } \\
\hline Kartabo & $0622 \mathrm{~N}, 5840$ & Beebe 1946 \\
\hline Laluni & $0622 \mathrm{~N}, 5751$ & Hoevers 1967 \\
\hline McTurk's Homestead & $0345 \mathrm{~N}, 5915$ & Allen \& Neill 1957 \\
\hline Torani River ${ }^{1}$ & 0546 N, 5741 & Gloyd 1940 \\
\hline \multicolumn{3}{|l|}{ SURINAM } \\
\hline Matappica Beach & $0557 \mathrm{~N}, 5454$ & Abuys 1987 \\
\hline Zanderij & $0527 \mathrm{~N}, 5517$ & Hoge 1964 \\
\hline \multicolumn{3}{|l|}{ FRENCH GUIANA } \\
\hline Canal Magnan & $0543 \mathrm{~N}, 5344$ & Gasc \& Rodrigues 1980 \\
\hline \multicolumn{3}{|l|}{ BRASIL } \\
\hline $\begin{array}{l}\text { Amazonas } \\
\text { Parintins } \\
\text { Bahia }\end{array}$ & 0237,5644 & Bates 1864 \\
\hline Angicos & 1513,4110 & Wied 1821 \\
\hline Mina Caraíba & 0950,3952 & Hoge 1966 \\
\hline $\begin{array}{l}\text { Salvador } \\
\text { Ceará }\end{array}$ & Ceará & Wucherer 1861, 1863, 1867 \\
\hline Aroeira & 0402,3824 & Gomes 1918 \\
\hline Juatama (formerly Floriano Peixoto) & 0505,3902 & Gomes 1918 \\
\hline Quixadá & 0458,3902 & Gomes 1918 \\
\hline São Vicente & 0324,4016 & Gomes 1918 \\
\hline Uruquê & 0509,3910 & Gomes 1918 \\
\hline \multicolumn{3}{|l|}{ Ceará/Rio Grande do Norte } \\
\hline \multicolumn{3}{|l|}{ Mato Grosso } \\
\hline Barracão Queimado & 1345,5943 & Silva 1993 \\
\hline Chapada dos Guimarães & 1526,5545 & Cope 1887 , Gloyd $1940^{2}$ \\
\hline Mato Verde & 1113,5040 & Hoge 1953b \\
\hline Vila Bela da Santíssima Trindade & 1501,5957 & Amaral 1926 \\
\hline Xavantina & 1440,5221 & Hoge $1953 b$ \\
\hline \multicolumn{3}{|l|}{ Mato Grosso do Sul } \\
\hline Arapuá & 2048,5202 & Amaral 1925a \\
\hline Campo Grande & 2027,5438 & Amaral 1925a \\
\hline Carandazal & 1948,5711 & Amaral 1925a \\
\hline Corumbá & 1900,5739 & Amaral 1925a \\
\hline Guaicurus & 2004,5646 & Amaral 1925a \\
\hline Miranda & 2015,5622 & Koslowsky 1898a, Amaral 1925a \\
\hline Porto Esperança & 1936,5727 & Amaral 1925a \\
\hline Urucum & 1910,5739 & Peracca 1904 \\
\hline
\end{tabular}




\section{APPENDIX I ( continuation )}

\begin{tabular}{|c|c|c|}
\hline Locality & Coordinates & Authority \\
\hline \multicolumn{3}{|l|}{ Minas Gerais } \\
\hline Alfenas & 2126,4557 & Sazima \& Di Bernardo 1992 \\
\hline Djalma Dutra & 2004,4501 & Renault \& Schreiber 1951 \\
\hline Lagoa Santa & 1938,4353 & Warming 1892, Jensen 1900 \\
\hline Monte Cristo & 2121,4625 & Amaral 1933 \\
\hline Ouro Fino & 2217,4623 & Carrillo de Espinoza 1983 \\
\hline Santa Rita da Extrema & 2252,4639 & Gloyd 1940 \\
\hline Uberlândia & 1855,4815 & Brites \& Bauab 1989 \\
\hline \multicolumn{3}{|l|}{ Pará } \\
\hline Condeixa & 0054,4836 & Nascimento et al. 1991 \\
\hline Serra do Ererê & 0153,5411 & De Witte 1930 \\
\hline Lago Mariapixí & 0155,5616 & Ducke 1913 \\
\hline Santarém & 0225,5448 & Bates 1864 \\
\hline \multicolumn{3}{|l|}{ Paraná } \\
\hline Campo Mourão & 2403,5222 & Bernils, Moura-Leite \& Ajuz 1990 \\
\hline Japira & 2348,5009 & Hoge $1953 \mathrm{c}$ \\
\hline Piraí do Sul & 2431,4957 & Gloyd 1940 \\
\hline Vila Velha & 2513,5000 & Bernils \& Moura-Leite 1990 \\
\hline \multicolumn{3}{|l|}{ Pernambuco } \\
\hline Carnaubeira & 0818,3845 & $\begin{array}{l}\text { Cordeiro \& Hoge } 1974 \text {, } \\
\text { Vanzolini et al. } 1980\end{array}$ \\
\hline Exu & 0731,3943 & Vitt \& Vangilder 1983 \\
\hline Jaboatão & 0807,3501 & Cordeiro \& Hoge 1974 \\
\hline Ouricurí & 0753,4005 & Miranda \& Miranda 1982 \\
\hline Recife & 0802,3453 & Cordeiro \& Hoge 1974 \\
\hline Tapacurá & 0800,3503 & Morais \& Morais 1987 \\
\hline \multicolumn{3}{|l|}{ Rio de Janeiro } \\
\hline Niterói & 2255,4305 & Gloyd 1940 \\
\hline \multicolumn{3}{|l|}{ Rio Grande do Sul } \\
\hline Ilha Barba Negra & 3028,5109 & Lema 1994 \\
\hline Cazuza Ferreira & 2857,5040 & Araujo \& Perazzolo 1974 \\
\hline Julio de Castilhos & 2919,5340 & Hoge 1966 \\
\hline Pelotas & 3145,5220 & Magalhães 1922, 1925, P. Müller 1971a \\
\hline Porto Alegre & 3000,5110 & Lema et al. 1980 \\
\hline Rio Pardo & 2958,5222 & Hensel 1868 \\
\hline Santa Cruz do Sul & 2943,5226 & Hensel 1868 \\
\hline Santana da Boa Vista & 3052,5307 & Lema 1994 \\
\hline Santana do Livramento & 3053,5531 & Lema 1994 \\
\hline São Marcos & 2858,5104 & Lema 1994 \\
\hline Viamão & 3005,5102 & Lema et al. 1980 \\
\hline \multicolumn{3}{|l|}{ Rondonia } \\
\hline Vilhena & 1242,6006 & Silva 1993 \\
\hline \multicolumn{3}{|l|}{ Roraima } \\
\hline Boa Vista & $0249 \mathrm{~N}, 6040$ & Hoge \& Romano 1969 \\
\hline Colonia Coronel Motta & $0318 \mathrm{~N}, 6102$ & Cunha \& Nascimento 1980 \\
\hline Limão, Rio Cotingo & $0356 \mathrm{~N}, 6030$ & Gloyd 1940 \\
\hline
\end{tabular}




\section{APPENDIX I ( continuation )}

\begin{tabular}{|c|c|c|}
\hline Locality & Coordinates & Authority \\
\hline $\begin{array}{r}\text { Ilha de Maracá } \\
\text { São Paulo }\end{array}$ & $0325 \mathrm{~N}, 6140$ & O’Shea 1989 \\
\hline Agua Vermelha & 2154,4753 & Belluomini \& Autuori 1983 \\
\hline Araçatuba & 2112,5025 & Amaral 1926c, 1933, Santos \& Germano 1996 \\
\hline Rio Feio & 2202,4929 & Ihering 1911 \\
\hline Franca & 2033,4724 & Ihering 1911, Gonçalves 1956 \\
\hline Helvetia & 2304,4710 & Gloyd 1940 \\
\hline Ilha Solteira & 2023,5121 & Hoge et al. 1975 \\
\hline Ipauçu & 2303,4957 & Amaral 1933 \\
\hline Ituverava & 2020,4748 & Gonçalves 1956 \\
\hline Itu & 2317,4718 & Amaral 1926a \\
\hline Jurucê (formerly Sarandy) & 2105,4745 & Amaral 1926b \\
\hline Limeira & 2234,4956 & Amaral 1934 \\
\hline Martinho Prado & 2119,4809 & Gloyd 1940 \\
\hline Morro Agudo & 2044,4804 & Gonçalves 1956 \\
\hline Palmar & 2040,4834 & Prado \& Barros, 1940, 1941 \\
\hline Piracicaba & 2242,4738 & Ihering 1911 \\
\hline Piraju & 2312,4923 & Gloyd 1940 \\
\hline São José do Rio Pardo & 2136,4654 & Amaral 1926a \\
\hline São José dos Campos & 2311,4553 & Boulenger 1896 \\
\hline São Paulo & 2332,4637 & Ihering 1911, Gloyd 1940 \\
\hline São Roque & 2342,4708 & Amaral 1926a \\
\hline Tocantins & & \\
\hline Barra do São Domingos & 1243,4746 & Amaral 1935 \\
\hline Cana Brava & 1247,4653 & Amaral 1935 \\
\hline \multicolumn{3}{|l|}{ BRASIL / PARAGUAY } \\
\hline Represa de Itaipu & 2526,5435 & Dure-Rodas 1995 \\
\hline \multicolumn{3}{|l|}{ PERU } \\
\hline Puno & & \\
\hline Sandia (provincia) & 1350,6920 & Schmidt \& Walker 1943 \\
\hline San Juan del Oro & 1412,6910 & Carrillo de Espinoza 1983 \\
\hline \multicolumn{3}{|l|}{ BOLIVIA } \\
\hline \multicolumn{3}{|l|}{ Santa Cruz } \\
\hline Buenavista & 1727,6340 & Gloyd 1940 \\
\hline La Florida & 1435,6050 & $\begin{array}{l}\text { Fugler \& De la Riva 1990, De la Riva, } \\
\text { Castroviejo \& Cabot } 1992\end{array}$ \\
\hline Parque Nacional Noel Kempff Mercado & 1419,6055 & Harvey et al. 1998 \\
\hline Piray & 1829,6351 & Gloyd 1940 \\
\hline Santa Cruz de la Sierra & 1748,6310 & Griffin 1916, Fugler \& De la Riva 1990 \\
\hline Vallegrande & 1829,6406 & Fugler \& De la Riva 1990 \\
\hline \multicolumn{3}{|l|}{ PARAGUAY } \\
\hline Alto Paraguay & & \\
\hline Rio Apa & 2205,5800 & Peracca 1895 \\
\hline $\begin{array}{l}\text { Fortin Teniente Martinez } \\
\qquad \text { Amambay }\end{array}$ & 2100,5946 & Aquino et al. 1996 \\
\hline Parque Nacional Cerro Corá & 2238,5601 & Aquino et al. 1996 \\
\hline
\end{tabular}




\section{APPENDIX I ( continuation )}

\begin{tabular}{|c|c|c|}
\hline Locality & Coordinates & Authority \\
\hline Boquerón & & \\
\hline $\begin{array}{l}\text { Filadelfia } \\
\qquad \text { Cañendiyú }\end{array}$ & 2221,6002 & Aquino et al. 1996 \\
\hline Curuguaty & 2427,5538 & Aquino et al. 1996 \\
\hline $\begin{array}{l}\text { Reserva Biológica Mbaracayu } \\
\quad \text { Central }\end{array}$ & 2425,5526 & Aquino et al. 1996 \\
\hline $\begin{array}{l}\text { Asunción } \\
\text { Chaco }\end{array}$ & 2519,5741 & Boulenger 1894 \\
\hline $\begin{array}{l}\text { Parque Nacional Defensores del Chaco } \\
\text { Concepción }\end{array}$ & 22038,5952 & Aquino et al. 1996 \\
\hline $\begin{array}{l}\text { Estancia Centurión } \\
\text { Guairá }\end{array}$ & 2215,5735 & Aquino et al. 1996 \\
\hline $\begin{array}{l}\text { Independencia } \\
\text { Nueva Asunción }\end{array}$ & 2543,5615 & Gloyd 1940 \\
\hline Km 530 Ruta 9 & 2206,6029 & Aquino et al. 1996 \\
\hline km 605 Ruta 9 & 2139,6105 & Aquino et al. 1996 \\
\hline $\begin{array}{l}\text { Parque Nacional Teniente Enciso } \\
\text { Paraguarí }\end{array}$ & 2113,6149 & Aquino et al. 1996 \\
\hline $\begin{array}{c}\text { Parque Nacional Ybycui } \\
\text { Presidente Hayes }\end{array}$ & 2614,5703 & Aquino et al. 1996 \\
\hline Estancia Juan de Zalazar & 2304,5913 & Aquino et al. 1996 \\
\hline Km 150 Ruta 9 (Transchaco) & 2413,5807 & Aquino et al. 1996 \\
\hline Km 344 Ruta 9 (Transchaco) & 2315,5916 & Aquino et al. 1996 \\
\hline $\begin{array}{l}\text { Ruta } 9 \text { (Transchaco) at Rio Verde } \\
\text { San Pedro }\end{array}$ & 2311,5914 & Scott \& Lovett 1975 \\
\hline Colonia Rio Verde & 2350,5608 & Aquino et al. 1996 \\
\hline \multicolumn{3}{|l|}{ ARGENTINA } \\
\hline Chaco & & \\
\hline Resistencia & 2727,5900 & Peracca 1895, Berg 1898 \\
\hline $\begin{array}{l}\text { Tres Palmas } \\
\text { Cordoba }\end{array}$ & 2644,5959 & Berg 1898 \\
\hline $\begin{array}{l}\text { Rio Primero } \\
\text { Entre Rios }\end{array}$ & 3120,6337 & Foote \& MacMahon 1977 \\
\hline $\begin{array}{c}\text { Puerto Algarrobo } \\
\text { Formosa }\end{array}$ & 3038,5935 & Freiberg 1939, Vuoto 1995 \\
\hline $\begin{array}{c}\text { Reserva El Bagual } \\
\text { Mendoza }\end{array}$ & 2611,5857 & Yanosky 1989 \\
\hline $\begin{array}{r}\text { General Alvear } \\
\text { Misiones }\end{array}$ & 3458,6742 & Sage \& Capredoni 1971 \\
\hline Aristobulo del Valle & 2706,3450 & Giraudo \& Abranson 1994 \\
\hline Monte Carlo & 2634,5447 & Freiberg 1939 \\
\hline Oberá & 2729,5507 & Cei 1993 \\
\hline Parque Nacional del Iguazu & 2543,5425 & $\begin{array}{l}\text { Montanelli \& Acosta 1991, } \\
\text { Acosta et al. } 1994\end{array}$ \\
\hline
\end{tabular}




\section{APPENDIX I ( continuation )}

\begin{tabular}{l|l|l}
\hline Locality & Coordinates & Authority \\
\hline \multicolumn{1}{c|}{ San Juan } & 3149,6712 & Cei \& Castro 1978a,b \\
Guayaguas & 3129,6720 & Cei \& Castro 1978a,b \\
Marayes & & \\
$\quad$ San Luis & 3213,6636 & Sage \& Capredoni 1971 \\
La Botija & 3413,6635 & Sage \& Capredoni 1971 \\
Las Tres Cañadas & 3447,6611 & Sage \& Capredoni 1971 \\
Nahuel Mapa & 3336,6608 & Sage \& Capredoni 1971 \\
San Francisco del Monte (de Oro) & 3318,6622 & Sage \& Capredoni 1971 \\
San Luis & 3348,6636 & Sage \& Capredoni 1971 \\
Zanjitas & & \\
$\quad$ Santiago del Estero & 2900,6208 & Miranda et al. 1985 \\
Guardia Escolta & & Abalos \& Nader 1967 \\
Pozo Herrado & & \\
\hline URUGUAY & 3450,5508 & Lema 1994 \\
\hline \multicolumn{1}{c}{ Maldonado } &
\end{tabular}

${ }^{1}$ In Gloyd (1940), as elsewhere in the literature, misspelled "Toroni Road". I owe the correction to Dr. Greg Schneider, University of Michigan Museum of Zoology. ${ }^{2}$ Gloyd (1940) has this locality misspelled "Chapadão" and placed in the state of S. Paulo. I owe the correction to Dr. Ned S. Gilmore, Academy of Natural Sciences of Philadelphia. ${ }^{3}$ Gloyd (1940) has this locality as San Sebastian, "Monagas, Venezuela". I owe the correction to Drs. James Hanken and José Rosado, Museum of Comparative Zoology.

\section{APPENDIX II}

\section{Generic localities of South American Crotalus}

ARGENTINA

General

Cope 1899

Di Tada \& Abalos 1976

Cei 1986

Williams \& Francini 1991

Chaco

Gallardo 1979

Bucher 1980

Córdoba

Weyenbergh 1876

Mendoza

Burmeister 1861

Misiones

Gallardo 1986
Martinez, Martinez \& Montanelli 1992

Santiago del Estero

Esteso \& Urtubey 1983

"Districto chaqueño",

Leynaud \& Bucher 1999

\section{BOLIVIA}

La Paz

"Caupolicam', = Provincia Franz Tamayo Boulenger 1896

Santa Cruz

Provincia Chiquitos

Guichenot 1855

Provincia Sara

Griffin 1916

"Districto chaqueño",

Leynaud \& Bucher 1999 
BRASIL

Amapá

Hoge 1967

Bahia

Gunther 1861

Wucherer 1861, 1863

Mato Grosso

Chapada dos Guimarães

Cope 1887

Pará

Ilha de Marajó

Lacerda 1884

Yuki \& Santos 1996

Pernambuco

Boulenger 1896

Rio Grande do Sul

General

Hensel 1868

Boulenger 1886

Boettger 1898

Greater Porto Alegre

Fundação Zoo-botânica 1976

Roraima

Lacerda 1884

\section{COLOMBIA}

General

Perez-Santos \& Moreno 1988

GUIANAS

General

Hoogmoed 1979

FRENCH GUIANA

General

Chippaux 1986

Starace 1998

"Savannes côtières"

Lescure 1986

GUYANA

General

Quelch 1898

Beebe 1919

Parker 1935

\section{PARAGUAY}

General

Schenkel 1901

Bertoni 1913, 1913a

Amaral 1925b

\section{Canese 1966}

Alto Paraná

Bertoni 1939

"Districto chaqueño",

Leynaud \& Bucher 1999

PERU

Madre de Dios

Carrillo de Espinoza \& Icochea 1995

\section{SURINAM}

Kappler 1885

\section{URUGUAY}

General

Devincenzi 1925, 1929, 1939

Achaval \& Olmos 1997

Artigas

Vaz-Ferreira \& Sierra de Soriano 1960

Tacuarembó

Devincenzi 1925

VENEZUELA

General

Ernst 1877

\section{REFERENCES}

(The references marked with an asterisk contain references to rattlesnakes but are not relevant in the present context)

*Abalos JW, Baez EC and Nader R. 1964. Serpientes de Santiago del Estero. Acta Zool Lillo 20: 211-352.

*Abalos JW and Bucher E. 1970. Zoo-epidemiologia del ofidismo em Santiago del Estero. Bol Acad Nac Ci Córdoba 47(2-4): 259-272.

Abalos JW ANd Mischis CC. 1975. Elenco sistemático de los ofidios argentinos. Bol Acad Nac Ci Córdoba 51(1-2): 55-76.

Abalos JW and Nader R. 1967. Un caso de modificación cromática en Crotalus durissus terrificus. Rev Fac Ci Córdoba 28(1-4): 7-12.

*ABuys A. 1982. Enige korrekties en aanvullende gegevens het boekje ' Surinaamse slangen in kleur', van Joep Moonen e.a., 1979. Litt Serp 2(1): 34-42.

Aвuys A. 1987. The snakes of Surinam part XIX: Family Viperidae subfamily Crotalinae (genus Crotalus). Litt Serp 7(6): 282-296. 
*Achaval F. 1976. Reptiles, p. 26-29 in Langguth A (ed.) Lista de las especies de vertebrados del Uruguay. Montevideo: Facultad de Humanidades y Ciencias, Dept. Zool. - Vertebrados. 53 p.

*Achaval F. 1987. Lista de las especies de vertebrados del Uruguay. Reptiles. Montevideo: Faculdad de Humanidades y Ciencias. ii +15 p.

*Achaval F. 1989. Lista de especies de vertebrados del Uruguay. Parte 2. Anfibios, reptiles, aves y mamiferos. Montevideo: Facultad de Humanidades y Ciencias. 41p.

*Achaval F, Melgarejo A and Meneghel M. 1976. Viboras venenosas del Uruguay. Montevideo: Inst Invest $\mathrm{Ci} \mathrm{Biol} 6 \mathrm{p}$.

Achaval F, Melgarejo A and Meneghel M. 1978. Ofidios del area de influencia de Salto Grande. V Reunión sobre aspectos de desarrollo ambiental (Salto/(R.O.U.) - Concordia (R.A.), 6-10.xi.1978 Com Tecn Mixta Salto Grande (52 RDA/78/2/6): $35 \mathrm{p}$.

Achaval F and Olmos A. 1997. Anfibios y reptiles del Uruguay. Montevideo: edición de los autores. 128 p.

Acosta S, Giraudo A and Montanelli S. 1994. Composición de la ofidiofauna (Reptilia: Serpentes) del Parque Nacional Iguazu, Provincia de Misiones, Argentina. Bol Asoc Herp Argent 10(1): 6-10.

Aleman-G C. 1952. Apuntes sobre reptiles y anfibios de la region Baruta-El Hatillo. Mem Soc Ci La Salle (Caracas) 12(31): 11-30.

Aleman-G C. 1953. Contribución al estudio de los reptiles y batracios de la Sierra de Perijá. Mem Soc Ci La Salle (Caracas) 13(35): 205-225.

Allen ER and Neill WT. 1957. Some interesting rattlesnakes from southern British Guiana. Herpetologica 13(1): 67-74

*Amaral A. 1925a. Ophidios de Matto Grosso (Contribuição II para o conhecimento dos ophidios do Brasil). Comm. Linhas Telegr. Estrat. Matto Grosso ao Amazonas, Publ. 84, Anexo 5, Hist Nat, Zool: 1-29, pls. S. Paulo: Cia Melhoramentos. (republished 1948 with spelling changes).

*Amaral A. 1925b. South American snakes in the collection of the United States National Museum. Proc US Nat Mus 67(24): 1-30.

Amaral A. 1926a. Collectanea ophiologica. 1. Al- binismo em "Cobra coral”. Rev Mus Paulista 15: $1-9$, pls.

Amaral A. 1926b. Collectanea ophiologica. 6. Da ocorrência de albinismo em Cascavel, Crotalus terrificus (Laur.). Rev Mus Paulista 15: 55-57, pl.

Amaral A. 1926c. Collectanea ophiologica. 12. Variações das marcas dorsaes de Crotalus terrificus Laurenti, 1768. Rev Mus Paulista 15: 89-91.

Amaral A. 1926d. Collectanea ophiologica. 13. Bicephalia em ophidios. Rev Mus Paulista 15: 95-101, 6 pls.

*Amaral A. 1927. Contribuição à biologia dos ophidios brasileiros (Habitat, hábitos, alimentação). Primeira nota previa. Collect Trabalhos Inst Butantan 2 (191821): 175-181.

Amaral A. 1928. Studies on Neotropical Ophidia. 11. Snakes from the Santa Marta region, Colombia. Bull Antiven Inst Amer 2(1): 7-8.

Amaral A. 1929a. Key to the rattlesnakes of the genus Crotalus Linné, 1758. Bull Antiven Inst Amer 3(1): 4-6.

*Amaral A. 1929b. Phylogenia das cascaveis. An Soc Cient Argent 107: 371-373.

*Amaral A. 1930a. Estudos sobre ophidios neotropicos XVIII. Lista remissiva dos ophidios da região neotropica. Mem Inst Butantan 4 (1929): viii + 129 271.

*Amaral A. 1930b. Estudos sobre ophidios neotropicos XVIII. Valor systematico de varias formas de ophidios neotropicos. Mem Inst Butantan 4 (1929): 1-68.

Amaral A. 1930c. Contribuição ao conhecimento dos ophidios do Brasil. IV. Lista remissiva dos ophidios do Brasil. Mem Inst Butantan 4 (1929): 71-125.

Amaral A. 1931a. Studies of Neotropical Ophidia. XXIII. Additional notes on Colombian snakes. Bull Antiven Inst Amer 4(4): 85-89.

Amaral A. 1931b. Studies of Neotropical Ophidia. XXVI. Ophidia of Colombia. Bull Antiven Inst Amer 4(4): 89-94.

Amaral A. 1931c. Serpientes venenosas sudamericanas. Sexta Reunión de la Sociedad Argentina de Patologia Regional del Norte (1931): 788-805.

Amaral A. 1931d. Serpientes venenosas sul americanas. Arch. Soc Biol Montevideo 1930 Supl. (1): 93-107. (Actas Congr Int Biol Montevideo, 7-12 
octubre 1930).

Amaral A. 1933a. Notas sobre chromatismo de ophidios. II: Casos de variação de colorido de certas serpentes. Mem Inst Butantan 7 (1932): 81-87, 8 pls.

Amaral A. 1933b. Contribuição à biologia dos ophidios do Brasil. IV. Sobre um caso de necrofilia heteróloga na jararaca (Bothrops jararaca). Mem Inst Butantan 7(1932): 93-94.

Amaral A. 1933c. Sobre um caso de necrofilia heteróloga na jararaca (Bothrops jararaca). Bol Biol (S. Paulo) (N.S.) 1(1): 1-2.

Amaral A. 1934. Notas sobre chromatismo de ophidios. III. Um caso de xanthismo e um novo de albinismo observados no Brasil. Mem Inst Butantan 8: 151153.

Amaral A. 1935. Collecta herpetologica no centro do Brasil. Mem Inst Butantan 9: 235-246.

Amaral A. 1937a. Herpetological collection from Central Brasil. C.R. XII Congr. Int. Zool. (Lisbonne, 1935) 3: 1720-1732 (republication of Amaral. 1935; see Vanzolini, 1978: 94).

Amaral A. 1937b. Contribuição ao conhecimento dos ophidios do Brasil. VIII. Lista remissiva dos ophidios do Brasil. 2a. edição. Mem Inst Butantan 10 (1935/36): 87-162, i-xix.

Amaral A. 1937c. Check-list of the Ophidia of Brasil. CR XII Congr Int Zool (Lisbonne, 1935) 3: 17441761. (see Vanzolini, 1978: (4).

Amaral A. 1938. Contribuição ao conhecimento dos ophidios do Brasil. II. Synopse das crotalideas do Brasil. Mem Inst Butantan 11 (1937): 217-229.

*Amaral A. 1944. Notas sobre a ofiologia neotrópica e brasílica. V. Sobre a invalidez específica de Crotalus unicolor. Papéis Avulsos Dep Zool S Paulo 5: 29-40.

Amaral A. 1949. Ofídios do Pará. Bol Mus Para Emílio Goeldi 10: 149-159.

*Amaral A. 1977. Serpentes do Brasil. Iconografia colorida. S. Paulo: Melhoramentos/Inst Nac Livro/ Ed Univ S Paulo. 247p. (bilingual text, PortugueseEnglish).

Andersson LG. 1899. Catalogue of Linnean type-specimens of snakes in the Royal Museum in Stockholm. Bih t K Svenska Vet - Akad Handl 24(4) art. 6: 35p.

Andersson LG. 1900. Catalogue of the Linnean typespecimens of Linnaeus's Reptilia in the Royal Mu- seum in Stockholm. Bih t K Svenska Vet - Akad Handl 24(4) art. 1: 29p.

Andrada E Silva J.B. D’. 1791. Observations sur le Crotalus horridus (Linné). Bull Sci Soc Philomat Paris 1: 4.

*Anthony J. 1955. Essai sur l'évolution anatomique de 1'appareil venimeux des ophidiens. Ann Sci Nat (II) 17: 7-53.

Aquino AL, Scott NJ And Motte M. 1996. Lista de anfibios y reptiles del Museo Nacional de Historia Natural del Paraguay (Marzo, 1980-Septiembre, 1995), p. 331-400 in Museo de Historia Natural del Paraguay, Colecciones de Flora y Fauna del Museo Nacional de Historia Natural del Paraguay.

*Araujo ML and Ely LAM. 1980. Notas sobre a biologia de tanatofídios criados em cativeiro - 2a. parte (Ophidia - Elapidae e Viperidae). Iheringia (Zool.) 55: 9-26.

Araujo ML and Perazzolo M. 1974. Nota prévia sobre a biologia de tanatofídios em cativeiro. (Ophidia, Elapidae e Viperidae). Iheringia (Zool.) (Porto Alegre) 45: 55-66.

*Armas RJ. 1931. Los ofidios y sus venenos. Tesis bachiller Univ Central Venezuela. 16p.

*D'Audretsch FC. 1968. Aantekeningen over amfibieën en reptielen in Suriname (XI). Lacerta 26(8): 64-68.

Aulard F-A. 1907. Entry "Bosc (Louis-AugustinGuillaume)', in La Grande Encyclopédie... sous la direction de Mm. Berthelot... E. Müntz. Vol. 7: 451-452. Paris: Larousse.

BAIRD SF AND GIRARD C. 1853. Catalogue of North American reptiles in the museum of the Smithsonian Institution. Part I. - Serpentes. xvi + 172p. Washington: Smithsonian Institution.

*Barbour T and Loveridge A. 1929. Typical reptiles and amphibians. Bull Mus Comp Zool 69: 205-360.

BARrio A. 1961. Consideraciones en torno a Crotalus terrificus crotaminicus Moura Gonçalves. Physis 22(63): 141-147.

Barrio A.(H.) AND Brazil OV. 1954. Acción neuromuscular de los venenos de Crotalus terrificus terrificus (Laur.). Rev Inst Malbran (Buenos Aires) 16(1): 22-40.

*BARth R. 1958. A fauna do Parque Nacional do Itatiaia. 
Bol Parq Nac Itatiaia 6 (1957): 1-140.

BAtes HW. 1864. The naturalist on the river Amazons. London: John Murray. xii + 466p., maps.

Battersby JC. 1971. G.A. Boulenger: his life and herpetological work, p. vii-xii in G.A. Boulenger, Contributions to American herpetology, collected papers. Facsimile edition, Society for the Study of Amphibians and Reptiles.

BEÇAK W. 1966. Constituição cromossômica e mecanismo de determinação do sexo em ofídios sul americanos. I. Aspectos cariotípicos. Mem Inst Butantan 32 (1965): 37-78.

BeÇAK W. 1967. Chromosome numbers and sex chromosomes in Serpentes. Chrom Newsl 8(1): 4-10.

*BeÇaK W. 1968. Karyotypes, sex chromosomes, and chromosomal evolution in snakes, p. 53-95 in W. Bücherl, E. Buckley \& V. Dieulofeu (eds.), Venomous animals and their venoms, vol. 1. New York and London: Academic Press.

*BeçaK W and BeÇaK ML. 1969. Cytotaxonomy and chromosomal evolution in Serpentes. Cytogenetics 8: $247-262$.

BeÇaK W, BeÇaK ML and Nazareth HRS. 1964. Cariótipos e cromossomos sexuais em serpentes. $\mathrm{Ci}$ Cult (S Paulo) 16: 123.

Bechstein JM. 1802. Herrn De la Cepede's Naturgeschichte der Amphibien, oder... Vol. 5. Weimar: Industrie Comptoir. xii $+200 p$.

Bechtel HB. 1978. Color and pattern in snakes (Reptilia, Serpentes). J Herp 12(4): 521-532.

BEEBE W. 1919. The higher vertebrates of British Guiana with special reference to the fauna of the Bartica District 7. List of Amphibia, Reptilia and Mammalia. Zoologica (New York) 2(7): 205-227.

BeEBE W. 1946. Field notes on the snakes of Kartabo, British Guiana, and Caripito, Venezuela. Zoologica (New York) 31(1): 11-52, pls.

Belluomini HE and Autuori MP. 1983. Methodology applied in the elaboration of faunal salvage in the region of "Agua Vermelha"' hydroelectric power plant, Centrais Energéticas de São Paulo - CESP. Mem Inst Butantan 46(1982): 119-138.

Belluomini He, De Biasi P, Puorto G and Borelli V. 1978. Bicefalia em Crotalus durissus terrificus (Laurenti). (Serpentes: Viperidae, Crotalinae). Mem
Inst Butantan 40/41(1976/77): 117-121.

Berg, C. 1898. Contribuciones al conocimiento de la fauna herpetológica argentina y de los paises limitrofes. An Mus Nac Buenos Aires 6: 1-32.

Bérnils RS And Moura-Leite JC. 1990. A contribuição de André Mayer à história natural no Paraná (Brasil) III. Répteis. Arq Biol Tecnol (Curitiba) 33(2): 469480.

Bérnils RS, Moura-Leite JC and Ajuz RG. 1990. Albinismo em Crotalus durissus (Serpentes: Viperidae) do estado do Paraná - Brasil. Biotemas, Florianópolis, 3(2): 129-132.

Berthold AA. 1846. Zoologisches Museum. Nachrichten von der G[eorgs] A[ugustus] Universität und der Königl. Gesellschaft der Wissenschaften zu Göttingen 8: 124-128; 9 (Fortsetzung): 129-144: 10 (Schluss): 145-151. Facsimile reprint paged 1-27 titled Über das zoologische Museum zu Göttingen. II Verzeichniss der aufgestellten Reptilien. Göttingen, Dieterichschen Buchhandlung 1846.

*Bertoni A.W. 1913. Fauna paraguaya. Catálogos sistemáticos de los vertebrados del Paraguay, 86p. in Moisés S. Bertoni (“Helvetius'”) Descriptión física y económica del Paraguay. Asunción.

*Bertoni AW. 1913a. Zoologia economica del Paraguay. III. Culebras ofiófagas en el Paraguay (Herpet). Agronomia (Asunción) 5(3-4): 114-116.

Bertoni AW. 1939. Catalogos sistematicos de los vertebrados del Paraguay. Reptiles y batracios. Rev Soc Cient. Paraguay 4: 40-49.

BISBAL-E. FJ. 1990. Inventario preliminar de la fauna del Cerro Santa Ana, Peninsula de Paraguaná - Estado Falcón, Venezuela. Acta Cient Venez 41: 177-185.

*Blair WF, Hulse AC and Mares MA. 1976. Origins and affinities of vertebrates of the North American Sonoran Desert and the Monte Desert of northwestern Argentina. J Biogeogr 3: 1-18.

BodDaERT P. 1783. Specimen novae methodi distinguendi serpentia. Nov Acta Phys-Med Acad Caes Leop-Carol Nat Cur 7: 12-27.

Boeseman M. 1970. The vicissitudes and dispersal of Albertus Seba's zoological specimens. Zool Med Rijksmus Leiden 44(13): 177-206, 4 pls.

Boettger O. 1898. Katalog der Reptilien-Sammlung im Museum der Senckenbergischen Naturforschenden 
Gesellschaft in Frankfurt am Main. II. Teil (Schlangen). Frankfurt a.M.: Geb. Knauer. ix + 160p.

BoIE F. 1827. Bemerkungen über Merrem's Versuch eines Systems der Amphibien, Marburg, 1820. Erste Lieferung: Ophidier. Isis von Oken 20: 508 - 565.

Bonnaterre JP. 1790a. Tableau encyclopédique et methodique des trois règnes de la nature. Ophiologie. Paris: Pancoucke. xliv + 176p., pls.

Bonnaterre J.P. 1790b. Encyclopédie méthodique. Tableau encyclopédique et methodique des trois règnes de la nature. Ophiologie. Paris: Pancoucke. xliv + $176 \mathrm{p}$.

Bory DE SAInT-VIncent JBGM. 1824. Dictionnaire classique d'Histoire Naturelle, par Messieurs Audouin..., et Bory de Saint-Vincent. Ouvrage dirigée par ce dernier collaborateur. Vol. 5. Paris: Rey et Gravier, Baudoin Frèrees.

*Boulenger GA. 1886. A synopsis of the reptiles and batrachians of the Province Rio Grande do Sul, Brazil. Ann Mag Nat Hist (5) 18: 423-445.

Boulenger GA. 1894. List of reptiles and batrachians collected by Dr. J. Bohls near Asuncion, Paraguay. Ann Mag Nat Hist (6) 13: 342-348.

Boulenger GS. 1896. Catalogue of the snakes in the British Museum (Natural History). Vol. 3. London: Trustees of the British Museum. xiv + 727p., pls.

BOWLER JK. 1977. Longevity of reptiles and amphibians in North American collections as of 1 November, 1975. SSAR Misc Publ, Herp Circ 6: 32p.

BRADLEY R. 1721. A philosophical account of the works of Nature... to which is added an account of the state of gardening, as it is now in Great Britain and other parts of Europe. London: xx + 194p., 28 pls.

Brattstrom BH. 1964. Evolution of the pit vipers. Trans San Diego Soc Nat Hist 13(11): 185-268.

*Brazil V. 1911. A defesa contra o ophidismo. S. Paulo: Pocai \& Weiss. 152p., pls.

*Brazil V. 1914. La défense contre l'óphidisme. Traduction française par le Professeur J. Maibon. 319p., pls. Saint-Paulo (S. Paulo): Pocai-Weiss et C.

Briceño-Rossi AL. 1934. El problema del ofidismo en Venezuela. Bol Minist Salubr Agric Cria, Caracas 2(14): 1079-1177; (15): 15-103. (v. Vanzolini, 1978: 85).

Brites VlC and Bauab FA. 1989. Fauna ofidiana do município de Uberlândia, Minas Gerais - Brasil. I. Ocorrência na área urbana. Rev Centr Biomed Univ Fed Uberlândia 4(1): 3-8.

Brongersma LD. 1940. Snakes from the Leeward Group, Venezuela and eastern Colombia. Studies on the fauna of Curaçao, Aruba, Bonaire and the Venezuelan Islands 2(8): 116-137.

*Brongersma LD. 1967. Poisonous snakes of Surinam. Mem Inst Butantan 33(1) (1966): 73-79.

BüCHERL W. 1963. Über die Ermittlung von Durschschnitts - und Höchst-Giftschlangen Südamerikas. Ein Beitrag zur Serumtherapie von Giftschlangenbissen, p. 67-120 in Die Giftschlangen der Erde, Behringswerk-Mitteilungen. Warnburg/Lahn: N.G. Elwert Universitäts-und Verlags-Buchhandlung.

Bucher EH. 1980. Ecología de la fauna chaqueña. Una revisión. Ecosur 7(14): 111-159.

Burmeister H. 1861. Reise durch die La Plata Staaten, mit besonderer Rücksicht auf die physische Beschaffenheit und den Culturalzustand der Argentinische Republik. Vol. 1: vi +502 p. Vol. 2: iv +538 p. Halle: H.W. Schmidt.

Burmeister G. 1944. Viaje por los estados del Plata... en los años 1857, ..., y 1860 por el... Buenos Aires: Unión Germánica en la Argentina. 3 vols.

Campbell JA and Lamar WW. 1989. The venomous reptiles of Latin America. Ithaca and London: Cornell University Press.xii $+425 p$.

*CAnese A. 1966. Animales venenosos del Paraguay. Rev Paraguaya MicroBiol 1(1): 56-72.

*CAnese A. 1970. Ejemplares de ofidios venenosos capturados en el Paraguay. Rev Paraguaya MicroBiol 5(1): 59-72.

*Carl G, Peterson KH and Hubbard RM. 1982. Reproduction in captive Uracoan rattlesnakes. Crotalus vegrandis. Herp Rev 13(2): 42-43.

Carrillo de Espinoza N. 1983. Contribución al conocimiento de las serpientes venenosas del Peru de las familias Viperidae, Elapidae e Hydrophiidae (Ophidia: Reptilia). Publ Mus Hist. Nat "Javier Prado"' (A, Zool) 30: 1-55.

CARrillo de Espinoza N AND ICOChea J. 1995. Lista taxonómica preliminar de los reptiles vivientes del Peru. Publ Mus Hist Nat Univ. Mayor San Marcos (A, Zool) 49: 1-27. 
Castelnau F. 1851. Expédition dans les parties centrales de l'Amérique du Sud..., sous la direction de... Histoire du voyage. Tome troisième. Paris: P. Bertrand. $484 \mathrm{p}$.

Castelnau F. 1852. Expédition dans les parties centrales de l'Amérique du Sud, de Rio de Janeiro a Lima, et de Lima au Para; ...pendant les années 1843 a 1847, ...Quatrième partie: Itinéraires et coupe géologique. Paris: P. Bertrand. viii, $76 \mathrm{pl}$.

Castelnau F. 1866. Relatorio dirigido ao ministro de instrucção publica pelo Sr. Castelnau, encarregado de uma commissão na America Meridional. Rev Trimens Hist Geogr 7 (2a. edição): 196-203.

Catesby M. 1731-1743. The Natural History of Carolina, Florida and the Bahama Islands:... 2 vols. London: W. Innys.

Cei JM. 1986. Reptiles del centro, centro-oeste y sur de la Argentina. Herpetofauna de las zonas áridas y semiáridas. Monogr. Mus Reg Sci Nat Torino 4: 527p., pls.

Cei JM. 1993. Reptiles del noroeste, nordeste y este de la Argentina. Monogr. Mus Reg. Sci Nat Torino 14: 949p.

*Cei JM and Castro LP. 1978a. Atlas de los vertebrados inferiores de la región de Cuyo. Publ. Ocas. Inst Biol Anim Fac Ci Agrar Univ Nac Cuyo (Ser. Cient.) 2: 38p. (colab. EA Ormeño and GF Arratia).

Cei JM and Castro LP. 1978b. Datos preliminares sobre las componentes de la herpetofauna de la provincia de San Juan. Publ Ocas Inst Biol Anim Fac Ci Agrar Univ Nac Cuyo (Ser. Cient.) 5: 4p.

Chace GE and Smith HM. 1968. Two additional examples of Gloyd's linked albinism in the prairie rattlesnake, Crotalus viridis. J Herp 2(3-4): 165-166.

Chippaux J-P. 1986. Les serpents de la Guyane Française. Paris: ORSTOM (Faune Tropicale 27). 165p.

*Chiszar D, Chiszar J, Walsh T, Demeter B and Sмітн HM. 1984. Effect of male courtship on strikeinduced chemosensory searching in a Uracoan rattlesnake (Crotalus vegrandis) at National Zoo. Bull Maryland Herp Soc 20(4): 145-151.

Collins JT and Knight JL. 1980. Crotalus horridus Linnaeus, Timber rattlesnake. Cat Amer Amph Rept 253: $1-2$.

Cope ED. 1860. Catalogue of the venomous serpents in the Museum of the Academy of Natural Sciences of Philadelphia, with notes on the families, genera and species. Proc Acad Nat Sci Philadelphia 1859: 332-347.

*Cope ED. 1862. Catalogues of the reptiles obtained during the explorations of the Parana, Paraguay, Vermejo and Uraguay rivers by Capt. Thos. J. Page and of those procured by Lieut. N. Michler, U.S. Top. Eng., commander of the expedition conducting the survey of the Atrato River. Proc Acad Nat Sci Philadelphia 1862: 346-359.

Cope ED. 1867. On the Reptilia and Batrachia of the Sonoran Province of the Nearctic Region. Proc Acad Nat Sci Philadelphia 1866: 300-314.

CoPe ED. 1884. Notes on the geographical distribution of Batrachia and Reptilia in western North America. Proc Acad Nat Sci Philadephia 1883: 10-35.

Cope ED. 1887. Synopsis of the Batrachia and Reptilia obtained by H.H. Smith in the Province of Matto Grosso, Brazil. Proc Amer Phil Soc 24: 44-60.

Cope ED. 1892. A critical review of the characters and variations of the snakes of North America. Proc US Nat Mus 14: 589-694.

Cope ED. 1895. The classification of the Ophidia. Trans Amer Phil Soc (N.S.) 18(2): 186-219, pls. 14-33.

Cope ED. 1899. Catalogue of a collection of Reptilia from Argentina. Sci Bull Philadelphia Commerc Mus 1: $19-21$

Cordeiro CL and Hoge AR. 1974. Contribuição ao conhecimento das serpentes do estado de Pernambuco. Mem Inst Butantan 37(1973): 261-290.

Coues E. 1875. Synopsis of the reptiles and batrachians of Arizona; with critical and field notes, and an extensive synonymy, chapt. 5, p. 585-633 in G.M. Wheeler, Report upon geographical and geological explorations and surveys west of the one-hundredth meridian, vol. 5. Washington, D.C.: Department of the Interior. Reprinted in Adler K, ed., 1978, Herpetological explorations of the Great American West. Vol. 1. New York: Arno Press.

Cunha ACM and Santos CA. 1991. Estudo morfológico comparado de duas populações de "cascavel”' (Crotalus durissus L., 1758) (Serpentes: Viperidae). Resumos XVIII Congr Brasil Zool (1991, Salvador): 340 (Abstract). 
Cunha OR and Nascimento FP. 1980. Ofidios da Amazônia. XI - Ofídios de Roraima e notas sobre Erythrolamprus bauperthuisii Duméril, Bibron \& Duméril, 1854, sinônimo de Erythrolamprus aesculapii aesculapii (Linnaeus, 1758). Bol Mus Para Emilio Goeldi (N.S., Zool) 102: 1-21.

Cunha OR and Nascimento FP. 1982. Ofidios da Amazônia XIV - As espécies de Micrurus, Bothrops, Lachesis e Crotalus do sul do Pará e oeste do Maranhão, incluindo areas de cerrado deste estado (Ophidia: Elapidae e Viperidae). Bol Mus Para. Emilio Goeldi (N.S., Zool) 112: 1-58.

Curran CH. 1935. Rattlesnakes. Nat Hist. November, 1935: 331-339.

Cuvier G. 1817. Le règne animal distribué d'après son organisation. Tome II, contenant les reptiles, les poissons, les mollusques et les annélidés. Paris: Deterville.

Cuvier G. 1829. Le Règne Animal distribué d'après son organisation,... Nouvelle édition... Tome 2. Paris: Deterville.

*Daniel Hno. 1949. Las serpientes en Colombia. Rev Fac Nac Agron. (Medellin) 10(36): 301-333.

*Daniel Hno. 1955. Algunos aspectos de la lucha biológica. IV. Rev Fac. Nac Agron. (Medellin) 17(48): 38-88.

Daubenton LJM. 1784. Les Animaux Quadrupèdes et les Serpens, p. 545-712 in Encyclopédie Méthodique..., par une societé de gens de lettres, de savans at d'artistes, Tome 2. Paris: Pancoucke.

DAudin FM AN XI. (1802). Histoire naturelle générale et particulière des reptiles. Vol. 5. Paris: F. Dufart. $365 \mathrm{p}$.

De la Riva de la Viña I, Castroviejo JB and Cabot NJ. 1992. Pseustes sulphureus (Wagler, 1824) (Serpentes: Colubridae) nueva especie para Bolivia y datos sobre la herpetofauna boliviana. Acta Zool Lillo 41 (Actas I Congr. Argent. I Congr. Sudamer. Herp.): 215-218.

Devincenzi G. 1925. Fauna erpetólogica del Uruguay. Ann. Mus Montevideo (2) 2(1): 1-65.

*Devincenzi G. 1929. Serpenti dell'Uruguay. Le vie d'Italia e dell'America Latina 35(5): 467-476.

*Devincenzi G. 1939. Ofidios del Uruguay. Montevideo: Soc Linneana, 53p.
Ditada IE And Abalos JE. 1976. Serpientes venenosas de la Argentina. Tratamiento de sus mordeduras. Publ. Centro Zool Apl. Univ. Nac Córdoba 5: 18p.

Ditmars RL. 1905. A new species of rattlesnake. Ninth Ann Rept New York Zool Soc: 24-28.

*Ditmars RL. 1912. The feeding habits of serpents. Zoologica, New York, 1(11): 197-238.

Ditmars RL. 1921. Albinos in the zoological park and elsewhere. Bull Zool Soc New York 24(6): 127-132.

*Ditmars R. 1930. The poisonous serpents of the New World. Bull New York Zool Soc 33: 79-99.

DonNDORFF JA. 1798. Zoologische Beyträge zur XIII. Ausgabe der Linneischen Natursystems. Dritter Band. Amphibien und Fische. Leipzig: Weidmann. $\mathrm{Vi}+225 \mathrm{p}$.

Ducke A. 1913. Explorações scientificas no Estado do Pará. Bol Mus Goeldi 7(1910): 100-197.

Ducke A AND Black GA. 1953. Phytogeographical notes on the Brazilian Amazon. An Acad Bras Cienc 25(1): 1-46.

DugAnd A. 1975. Serpentifauna de la llanura costera del Caribe. Caldasia (Bogotá) 11(53): 61-82. (posthumous article).

DumÉRIL AMC. 1853. Prodrome d'une classification des reptiles ophidiens. Mém Acad Sci Paris 23: 399-536.

Duméril A. 1861. Lettres de... relatives au catalogue des poissons... et au catalogue de la ménagerie des reptiles... suivies de notes sur la ménagerie des reptiles. Arch Mus Nat Hist Nat Paris 10: 429-460.

Duméril AMC, Bibron G. AND Duméril A. 1854. Erpétologie générale. Vol. 7(2): xii, 781-1536. Paris: Librairie Encyclopédique de Roret.

DumérIl [AM]C AND DumérIL A. 1851. Catalogue méthodique de la collection des Reptiles (Muséum d'Histoire Naturelle de Paris). Paris: Gide et Baudry. $\mathrm{Iv}+224 \mathrm{p}$.

*DunN ER. 1944. Los generos de anfibios y reptiles de Colombia. III. Tercera parte. Reptiles, orden de las serpientes. Caldasia (Bogotá) 3: 155-224.

Dure-Rodas A. 1995. Vertebrados del area de Itaipu: Estudio de reptiles y anfibios. Biota (Itaipu Binacional) 2: 20-24.

Duvernoy GL. 1832. Mémoire sur les caractères tirés de l'anatomie pour distinguer les serpens venimeux 
des serpens non venimeux. Ann. Sci Nat (Paris) 27: 113-160, pls.

Duvernoy GL. 1842. Le Règne Animal... par Georges Cuvier. Edition accompagnée de planches... par une réunion de disciples de Cuvier. Les Reptiles, avec un Atlas. 16ème livraison. Paris: Victor Masson. (for date see Sherborn, 1922; Cowan, 1976).

DYRKACZ S. 1981. Recent instances of albinism in North American amphibians and reptiles. SSAR Herp Circ 11: $31 \mathrm{p}$.

*Elter O. 1981. Cataloghi. V - La collezione erpetologica del Museo di Zoologia dell Universitá di Torino. Torino: Museo Regionale di Scienze Naturali. 116p.

D'Empaire A, Serrano JE, Cook G, Govea R, Leal MA, Rios JM And Cuenca H. 1921. Geografia médica del Zulia (Trabajo de contribución al Tercer Congreso Venezolano de Medicina). Cap. IV, Fauna, p. 76-83. Maracaibo: Empresa Panorama.

*Ernst A. 1877. Idea general de la fauna de Venezuela, p. 272-292 in Primer Anuario Estadistico. Caracas.

Esteso SC AND URTubey N. 1983. Normas básicas de procedimientos, terapeutica y prevención en ofidismo, araneismo y escorpionismo humanos. Inst Anim Ven “Dr. Jorge W. Abalos'” (Santiago del Estero) Ser Tecn 1: 30p.

Fermin P. 1769. Description générale, historique, géographique et physique de la colonie de Surinam. Tome second. Amsterdam: E. Van Harrevelt. 351p.

FigueiroA S. 1997. As ciências geológicas no Brasil: uma história social e institucional, 1875-1934. S. Paulo: Hucitec. 270p.

FILIPPI F DE. 1840. Catalogo ragionato e descrittivo della raccolta de serpenti del Museo dell' I.R. Universitá di Pavia. Biblioteca Italiana 99: 65p.

FISHER RA. 1938. Statistical methods for research workers. Seventh edition. London, Edinburgh: Oliver and Boyd.

*Fitch HS. 1981. Sexual size diferences in reptiles. Misc Publ Univ Kansas Mus Nat Hist. 70: 1-72.

FitzINGER LI. 1826a. Neue Classification der Reptilien nach ihren natürlichen Verwandschaften... Wien: J.G. Heubner. (facsimile reprint 1997, Society for the Study of Amphibians and Reptiles).

Fitzinger LI. 1826b. Critische Bemerkungen über J. Wagler's Schlangenwerk. Isis von Oken 19:
881-909.

FitzINGER L. 1843. Systema reptilium. Fasciculus primus, Amblyglossae. 106p. Vienna: Braunmüller et Seidel.

FLeming J. 1822. The philosophy of Zoology, or a general view of the structure, functions, and classification of animals. Vol. 2. Edinburgh: A. Constable; London: Hurst \& Robinson. 618p.

Foote R And MacMahon JA. 1977. Electrophoretic studies of rattlesnake (Crotalus \& Sistrurus) venom: taxonomic implications. Comp. Biochem. Physiol. 57 B: $235-241$.

FreIBERG MA. 1939. Enumeración sistemática de los reptiles de Entre Rios y list de los ejemplares que los representan en el Museo de Entre Rios. Mem Mus Entre Rios (Paraná) Zool 11: 28p.

Freiberg MA. 1968. Ofidios ponzoñosos de la Argentina. Ci Invest. 24(8) 338-353.

*Freiberg MA. 1982. Snakes of South America. Neptune, New Jersey: T.F.H. Publications. 189p., pls.

Fugler CM And De la Riva I. 1990. Herpetologia Boliviana. Lista provisional de las serpientes conocidas en el pais. Com. Mus Nac Hist. Nat La Paz 9: 22-53.

Fundação Zoobotânica do Rio Grande do Sul. 1976. Preceituação ecológica para a preservação dos recursos naturais na região da Grande Porto Alegre. Publ Avulsa FZB 1: 145p.

*Gallardo JM. 1977. Reptiles de los alrededores de Buenos Aires. Buenos Aires: Eudeba/Lectores. $213 p$.

Gallardo JM. 1979. Composición, distribución y origem de la herpetofauna chaqueña, p. 299-307 in W.E. Duellman, ed., The South American herpetofauna: its origin, evolution, and dispersal. Monogr Mus Nat Hist Univ Kansas 7: 485p.

GALlardo JM. 1986. La diversidad de la herpetofauna en la selva subtropical misionera. An Mus Hist Nat Valparaiso 17: 153-159.

Garcia E. 1896. Los ofidios venenosos del Cauca. xv + 102p., pls. Cali: Libreria Colombiana.

GARCIA-PÉrez JE. 1995. Una nueva especie de cascabel (Serpentes: Crotalidae) para el bolsón árido de Lagunillas, Cordillera de Mérida, Venezuela. Rev Ecol. Latin. - Amer. 3(1-3): 7-12.

Garman S. 1883. The reptiles and batrachians of North 
America. Part. I. Ophidia - Serpentes. Mem Mus Comp. Zool 8(3): xxx + 185p., pls.

GASC J-P AND Rodrigues M. 1980. Liste préliminaire des serpents de la Guyane française. Bull Mus Nat Hist Nat Paris (4) 2: 559-598.

*Gatti C. 1955. Las culebras venenosas del Paraguay. Rev Med. Paraguay 1: 81-100.

GiLbert SF. 2000. Developmental biology. Sixth edition. Sunderland, Massachusetts: Sinauer Associates. $x$ viii $+749 p$.

*GilboA I. 1975. Karyotypes of amphibians and reptiles: a bibliographic review, pp. 91-156 in H.G. Dowling (ed.), Yearbook of Herpetology. New York. Herpetological Information Search Service.

Gilboa I AND Dowling HG. 1974. A bibliography on albinism in amphibians and reptiles. Herp Inf Search Syst Publ 6: 11p.

Giraudo AR and Abranson R. 1994. Comentarios sobre los ofidios registrados en una localidad del centro de la Provincia de Misiones, Argentina. Bol Asoc Herp Argent 10(1): 8-9.

*Gliesch R. 1925. As cobras do estado do Rio Grande do Sul. Almanak Agricola Brasileiro 1925: 97-118.

Gloyd HK. 1935a. Some aberrant color patterns in snakes. Papers Michigan Acad Sci 20: 661-668.

Gloyd HK. 1935b. The cane-brake rattlesnake. Copeia 1935(4): 175-178.

GLOYD HK. 1936. The status of Crotalus unicolor van Lidth de Jeude and Crotalus pulvis Ditmars. Herpetologica 1(3): 65-68.

GLOYD HK. 1940. The rattlesnakes, genera Sistrurus and Crotalus. A study in zoogeography and evolution. Chicago Acad Sci Spec. Publ. 4: vii + $266+(4)$ p., pls. (facsimile reprint 1978, Society for the Study of Amphibians and Reptiles).

GLOYD HK. 1958. Aberrations in the color patterns of some crotalid snakes. Bull Chicago Acad Sci 10(12): 185:195.

GMelin JF. 1789. Caroli a Linné Systema Naturae... editio decima tertia, aucta, reformata, cura... Tomus I pars III. Leipzig: G.E. Beer.

GoldFuss GA. 1820. Reptilia: p. 121-181 in G.H. Schubert, Handbuch der Naturgeschichte zum Gebrauch bei Vorlesungen, Dritter Theil, Handbuch der Zoologie, zweite Abtheilung. Nürnberg: J.L. Schrag.
Gomes JF. 1918. Contribuição para o conhecimento dos ophidios do Brasil. II. Ophidios do Museu Rocha (Ceará). Rev Mus Paulista 10: 503-527.

GonçAlves JM. 1956. Estudos sobre venenos de serpentes brasileiras. II. Crotalus Terrificus Crotaminicus, subspécie biológica. An Acad Bras Cienc 28(3): 365-367.

Gonçalves JM and VieIRa LG. 1950. Estudos sôbre venenos de serpentes brasileiras. I - Análise eletroforética. An Acad Bras Cienc 22(1): 141-150.

*Gorman GC. 1973. The chromosomes of the Reptilia, a cytotaxonomic interpretation, p. 349-424, in Chiarelli AB and Capanna E, eds., Cytotaxonomy and vertebrate evolution. London and New York: Academic Press.

Gorzula S AND SEÑARIS JC. 1998. Contribution to the herpetofauna of the Venezuelan Guayana. I. A data base. Scientia Guaianae 8: xviii + 268p., pls, maps.

Grantsau R. 1991. Die Giftschlangen Brasiliens. S. Bernardo do Campo: Bandeirates. 101p., pls. (Brasilian translation, same date and publisher, “As cobras venenosas do Brasil'”).

GRAY JE. 1825.A synopsis of the genera of reptiles and amphibia, with a description of some new species. Ann Philos (2) 10: 193-217 (facsimile reprint 1966 Ohio Herpetological Society).

Gray JE. 1842. Synopsis of the species of Rattle-Snakes, or family of Crotalidae. Zool Misc. 47-51.

Gray JE. 1849. Catalogue of the specimens of snakes in the collection of the British Museum. $x v+125 p$. London: Trustees of the British Museum.

GrIFFIN LE. 1916. A catalog of the Ophidia from South America at present (June, 1916) contained in the Carnegie Museum, with descriptions of some new species. Mem Carnegie Mus Pittsburgh 7(3): 163277, pl. 28.

GronOviUs LT. 1754-1756. Museum Ichthyologicus (accedunt descriptiones Amphibiorum). 2 vols. Leiden.

Gronovius LT. 1763-1764. Zoophylacium Gronovianum. 3 vols. Leiden.

GuÉrin-MÉnEville FE. 1829-1844. Iconographie du Règne Animal de G. Cuvier... Avec un texte descriptif mis au courant... 3 vols. Paris, London: J. Baillière.

Guichenot A. 1855. Animaux nouveaux ou rares recueillis pendant l'expédition dans les parties cen- 
trales de l'Amérique du Sud, de Rio de Janeiro a Lima et de Lima au Para; executée par ordre du gouvernement français pendant les années 1843 a 1847, sous la direction du comte Francis de Castelnau. Tome Second, Reptiles. Livraisons 9-10, p. 65-80.

Gunther A. 1861. Account of the reptiles sent by Dr. Wucherer from Bahia. Proc Zool Soc London 1861: 12-18.

HAHN L. 1924. Entry “Palisot de Beauvois (Ambroise Marie-François-Joseph)', p. 884 in La Grande Encyclopédie... sous la direction de MM. Berthelot... E. Müntz. Vol. 25.

*Harris HS JR. ANd Simmons RS. 1972a. A checklist of the rattlesnakes (Crotalus durissus group) of South America. Bull Maryland Herp Soc 8(1): 27-32.

*Harris HS JR. ANd Simmons RS. 1972b. Keys to the Neotropical species and subspecies of the Crotalus durissus group. Bull Maryland Herp Soc 8(2): 3340.

Harris HS JR. AND Simmons RS. 1978a. A new subspecies of Crotalus durissus (Serpentes: Crotalidae) from the Rupununi savanna of Southwestern Guyana Inst Butantan 40/41 (1976-1977): 305-311.

*Harris HS JR. AND Simmons RS. 1978b. A preliminary account of the rattlesnakes with the descriptions of four new subspecies. Bull Maryland herp. Soc 14(3): 105-211.

Harvey MB et AL. 1998. Reptile and amphibian species of Parque Nacional Noel Kempff Mercado, Appendix 4, p. 348-355 in Killeen TJ and Schulenberg TS, eds., A biological assessment of Parque Nacional Noel Kempff Mercado, Bolivia.

Hemprich W. 1820. Grundriss der Naturgeschichte für höhere Lehranstalten. Erste Auflage. Berlin: August Rücker.

Hensel R. 1868. Beiträge zur Kenntniss der Wirbelthiere Süd-Brasiliens. (Fortsetzung). Arch. Naturg. 34(1): 323-375.

Hensley M. 1959. Albinism in North American amphibians and reptiles. Publ. Mus Michigan State Univ. (Biol) 1(4): 133-159.

Hermann J. 1804. Observationes zoologicae quibus novae complures,... Pars Prior, obervationum quatuor centurias continens. Argentières, Paris: A. Koening.

Hernandez F. 1651. Rerum medicarum Novae His- paniae thesaurus seu plantarum, animalium, mineralium mexicanorum historia... Roma: Mascardi. (xiv) $+950+(22)+90+(6) p$.

HigGINS SB. 1873. Ophidians: zoological arrangement of the different genera... New York and Philadelphia: Boerich \& Tafel.

Hoevers L. 1967. Herpetological collections from the Atkinson-Maduni-Laluni area, East Demerara, Guyana. Timehri 43: 34-59.

Hoge AR. 1953a. Notas erpetológicas. 1a. contribuição ao conhecimento dos ofidios do Brasil Central. Mem Inst Butantan 24(2) (1952): 179-214.

Hoge AR. 1953b. Notas erpetológicas. 2a. contribuição ao conhecimento dos ofidios do Brasil Central. Mem Inst Butantan 24(2) (1952): 215-224.

Hoge AR. 1953c. Herpetologische Notizen. Farbenaberrationen bei brasilianischen Schlangen. Mem Inst Butantan 24(2) (1952): 269-270.

Hoge AR. 1964. Serpentes da Fundação “'Surinaam Museum'. Mem Inst Butantan 30(1960-1962): 51-64.

Hoge AR. 1966. Preliminary account on Neotropical Crotalinae (Serpentes Viperidae). Mem Inst Butan$\tan$ 32(1965): 109-184.

Hoge AR. 1967. Serpentes do Território Federal do Amapá, p. 217-223 in H. Lent (ed.), Atas do Simpósio sobre a biota amazônica, vol. 5 (Zool.).

Hoge AR. 1979. Distribuição e dispersão de Crotalus durissus. An Acad Bras Cienc 51(3): 570-571 (abstract).

*Hoge AR and Lancini AR. 1962. Sinopsis de las serpientes venenosas de Venezuela. Publ Ocas Mus Ci Nat Caracas (Zool) 1: 1-24.

Hoge AR and Romano SA. 1969. Espécies registradas para o Brasil (Serpentes). Ci Cult (S. Paulo) 21(2): 454.

*Hoge AR and Romano SARWDL. 1971. Neotropical pit vipers, sea snakes, and coral snakes, p. 211-293 in Bücherl W and Buckley E (eds.), Venomous animals and their venoms. New York and London: Academic Press.

*Hoge AR and Romano SA. 1973. Sinopse das serpentes peçonhentas do Brasil. Serpentes, Elapidae e Viperidae. Mem Inst Butantan 36 (1972): 109-208.

Hoge AR, Romano SARWDL and CordeIro CL. 1978. Contribuição ao conhecimento das serpentes do 
Maranhão, Brasil (Serpentes: Boidae, Colubridae e Viperidae). Mem Inst Butantan 40/41 (1976/1977): 37-52.

Hoge AR, Romano SARWDL, Federsoni PA JR. AND CordeIro CLS. 1975. Lista das espécies coletadas na região da usina hidroelétrica de Ilha Solteira . Brasil. Mem Inst Butantan 38 (1974): 167-178.

Hoge AR And Romano-Hoge SARWDL. 1981a. Poisonous snakes of the world, Part I. Check list of the pit vipers, Viperoidea, Viperidae, Crotalinae. Mem Inst Butantan 42-43 (1978-1979): 179-309, pls.

Hoge AR and Romano-Hoge SARWDL. 1981b. Sinopse das serpentes peçonhentas do Brasil (2a. ed.). Mem Inst Butantan 42-43 (1978-1979): 373-497.

Hoge AR, Russo CR, Santos MC and Furtado MFD. 1981. Snakes collected by "Projeto Rondon XXII", to Piauí, Brazil. Mem Inst Butantan 42/43 (1978/79): 87-94.

Holm A. 1957. Specimina linneana i Uppsala bevarade zoologiska sammlingar fran Linnés tid. Uppsala Univ. Arsskr. 1957(6): 1-68.

Hoogmoed MS. 1979. The herpetofauna of the Guianan region, p. 241-279 in W.E. Duellman, ed., The South American herpetofauna: its origin, evolution and dispersal. Monogr. Mus Nat Hist. Univ. Kansas 7: $485 \mathrm{p}$.

*Hoogmoed MS. 1983. Snakes of the Guianan region. Mem Inst Butantan 46 (1982): 219-254. (Primeiro simpósio internacional sobre serpentes em geral e artrópodes peçonhentos).

Hoogmoed MS and Gruber U. 1983. Spix and Wagler type specimens of reptiles and amphibians in the Natural History Musea in Munich (Germany) and Leiden (The Netherlands), p. 319-415 in E.J. Fittkau \& L. Tiefenbacher (eds.), Festschrift zu Ehren von Dr. Johann Baptist Ritter von Spix. Spixiana Suppl. 9.

HoutTuYn M. 1764. Naturlyke of uitvoerige Beschryving der Dieren, Planten en Mineralen, volgens het Samenstel van den Heer Linneus. Eerste Deels, zesde Stuk. Dieren van beiderley Leeven. Amsterdam: published by the author. (iv) +560 p.

Humboldt A. 1813. Sur des nouvelles espèces de Crotales, p. 1-8 in A. de Humboldt \& A. Bonpland, Recueil d'observations de Zoologie et d'Anatomie Comparée faites dans l'Ocean Atlantique etc... Paris:
F. Schoell; G. Dufour.

ICZN (INTERNATIONAL COMMISSION ON ZOOLOGICAL NomenClature). 1926. Opinions rendered by the International Commission on Zoological Nomenclature. Opinions 91 to 97 . Smithsonian Misc. Coll. 73(4): 1-30.

ICZN (INTERNATIONAL COMMISSION ON ZOOLOGICAL NomenClature). 1999. International Code of Zoological Nomenclature. Fourth edition. London: The International Trust for Zoological Nomenclature. 306p.

IHeRING R v. 1911. As cobras do Brasil. Primeira parte. Rev Mus Paulista 8: 273-379.

*JaN G. 1857. Cenni sul Museo Civico di Milano ed indice sistematico dei rettili ed amphibi esposti nel medesimo. 61p. Milano: Museo Civico.

JAN G. 1859. Spix' Serpentes brasilienses bertheuilt nach Autopsie der Originalexempläre und auf die Nomenclatur von Duméril et Bibron zurückgeführt. Arch Naturg. 25(1): 272-275.

JAN G. 1863. Elenco sistematico degli ofidi descritti e disegnati per l'Iconographie Générale. vii + 143p. Milano: A. Lombardi.

JAN G AND SORDELLI F. 1874. Iconographie générale des ophidiens. Tome troisième, 46. livraison. Milan: chez les auteurs.

JEnSEn AS. 1900. Lagoa Santa Egnens Slanger. Vidensk. Med. naturh. Foren. Copenhagen 1900: 99-111.

Jonstonus J. 1650-1653. Historia naturalis de quadrupedibus... de serpentibus. Frankfurt. a. Main.

Kalm P. 1753 - 1761. En resa til Norra America etc. 3 vols. Stockholm.

KALM P. 1758. An account of the rattlesnake, and the cure of its bite, as used in North America, p. 282-293 in Haller AV, ed., Medical, Chirurgical and Anatomical cases and experiments. Reprinted in Adler K, ed., 1978, Herpetology in eastern North America during the "Naturalist's period"' (1725-1850). New York: Arno Press.

KAPPler A. 1885. Die Tierwelt im hollaendische Guiana. Ausland (Stuttgart) 40: 798-799; 41: 815-818; 42: 838-840; 43: 857-859.

KAPPler A. 1887. Surinam, sein Land, seine Natur, Bevölkerung und seine Kultur-Verhältnisse mit Bezug auf Kolonisations. Stuttgart: J.G. Cotta. 
383p., 1 map.

KaufFeld CF and Gloyd HK. 1939. Notes on the Aruba rattlesnake. Herpetologica 1(1): 156-160.

Kaup JJ. 1825. Einige Bemerkungen zu Merrems Handbuch. Isis von Oken 16(5): 589-593.

*Kempff-Mercado N. 1975. Ofidios de Bolivia. La Paz: Academia de Ciencias de Bolivia. 46p.

*KempfF-Mercado N. 1978. El genero Crotalus en Bolivia. Bol Inf. CENETROP 4(1-2): 52-56.

Klauber LM. 1936a. A statistical study of the rattlesnakes. I-III. Occ Pap San Diego Soc Nat Hist 1: $2-24$.

KLAuber LM. 1936b. A key to the rattlesnakes with a summary of characters. Trans San Diego Soc Nat Hist 8(2): 185-276, pls.

KLAuber LM. 1941. A new species of rattlesnake from Venezuela. Trans San Diego Soc Nat Hist 9(3): 333336.

Klauber LM. 1941. Four papers on the application of statistical methods to herpetological problems. The rattlesnakes listed by Linnaeus in 1758. Bull Zool Soc San Diego 17: 81-95.

Klauber LM. 1944. The sidewinder, Crotalus cerastes, with description of a new subspecies. Trans. San Diego Soc Nat Hist. 10(8): 91-126, pls.

Klauber LM. 1948. Some misapplications of the Linnaean names aplied to American snakes. Copeia 1948(1): 1-14.

KLAuber LM. 1956. Rattlesnakes, their habits, life histories, and influence on mankind. 2 vols. Berkeley and Los Angeles: published for the Zoological Society of San Diego by the University of California Press.

Klauber LM. 1972. Rattlesnakes, their habits, life histories, and influence on mankind. Second edition. 2 vols. Berkeley and Los Angeles: Published by the University of California Press for the Zoölogical Society of San Diego.

*Klemmer K. 1963. Liste der rezenten Giftschlangen, p. 255-464 in Die Giftschlangen der Erde, Behringswerk-Mitteilungen. Marburg/Lahn: N.G. Elwert Universitäts und Verlags-Buchhandlung.

KLUGE AG. 1984. Type-specimens of reptiles in the University of Michigan Museum of Zoology. Misc. Publ. Mus Zool Univ. Michigan 167: 1-85.
* Kова K. 1969. Introductory notes on Brazilian venomous snakes and the Instituto Butantan. Snake 1: 23-34.

Koslowsky J. 1898a. Ofidios de Mato Grosso (Brasil). Rev Mus La Plata 8: 25-32.

Koslowsky J. 1898b. Enumeración sistemática y distribución geográfica de los reptiles argentinos. Rev Mus La Plata 8: 161-200, 7 pls.

LACÉPÈDE BGEL COMTE DE. 1789. Histoire naturelle des serpens. Tome second. Paris: Imprimerie du Roi. 8 $+20+144+527 p$.

LACERDA JB. 1884. Leçons sur le venin des serpents du Brésil et sur la méthode de traitement des morsures par le permanganate de potasse. xv + 194p., 3 pls. Rio de Janeiro: Lombaerts.

*Lampe E. 1902. Catalog der Reptilien- und AmphibienSammlung (Schlangen; Frosch-, Schwanz- und Schleichenlurche) des naturhistorischen Museums $\mathrm{zu}$ Wiesbaden, mit Bemerkung von W.A. Lindholm. Jahrb. Nassau. Ver. Naturk. 55: 1-65.

LANCINI AR. 1962. Contribución al conocimiento de los ofidios del cordón litoral. Los ofidios de Curupao, estado Miranda (Venezuela). Acta. Biol Venez. 3(1): 161-172.

*Lancini VAR. 1979. Serpientes de Venezuela. Caracas: Ernesto Armitano. 262p., pls.

*Lancini AR and Kornacker P. 1989. Die Schlangen von Venezuela. Caracas: Verlag Armitano Editores CA 381p., pls.

LangGuth A. (ED.). 1976. Lista de las especies de vertebrados del Uruguay. Montevideo: Fac Human Ci, Dept. Zool - Vertebrados. 53p.

LANGLADA FG. 1975. Combat-dance between males of Brazilian Crotalus durissus. J Herp 9(4): 349-351.

*Langlada FG, Dias L, Penha AM and Machado JC. 1975. Contribuição ao estudo da patologia das serpentes Crotalus do Brasil. Dados médios de volumes e pesos ponderais de vísceras dessas serpentes (abstract). Ci Cult (S. Paulo) 27(7): Supl.: 363.

*Langlada FG, Falcão G. and Denaro L. 1975. Conservação de espermatozoides de serpentes Crotalus durissus. Estudo comparativo de alguns meios de cultura. Ci Cult (S. Paulo) 27(7) Supl.: 364. (Abstract).

Langlada FG, Gonçalves MF and Rodrigues ET. 
1974. Determinação da época de fecundidade em fêmeas do gênero Crotalus. Mem Inst Butantan 37 (1973): 253-260.

Latreille P. An X [1801a]. Tome III in C.S. Sonnini \& P. Latreille, Histoire naturelle des Reptiles. Seconde partie: Serpens. Paris: Deterville. 335p.

Latreille P. An X [1801b]. Tome IV in C.S. Sonnini et P. Latreille, Histoire Naturelle des Reptiles. Seconde partie, Serpens. Paris: Deterville. 410p.

LAurent RF AND TERAN EM. 1981. Lista de los anfibios y reptiles de la provincia de Tucumán. Misc Fund M Lillo 7: 1-15.

LAURENTI JN. 1768. Specimen medicus exhibens synopsin reptilium. Vienna: J. Thoma. $(6)+214+(2)$ p. (Facsimile edition 1966, A. Asher).

Le Conte J. 1853. Observations on the so-called Crotalus durissus and Crotalus adamanteus of modern authors. Proc Acad Nat Sci Philadelphia 6: 415-420.

*Leitão-Araujo M And Alves MLM. 1976. As serpentes peçonhentas do Rio Grande do Sul. Natureza em Revista (Porto Alegre) 1: 20-25.

*Lema T. 1973. As serpentes do estado do Rio Grande do Sul. Iheringia (Divulgação) (Porto Alegre) 3: 19-53.

*Lema T. 1983. Fauna de serpentes da provincia pampeana e inter-relações com as provincias limítrofes. Mem Inst Butantan 46 (1982): 173-182. (Primeiro Simpósio Internacional sobre serpentes em geral artrópodes peçonhentos).

LEMA T. 1994. Lista comentada dos répteis ocorrentes no Rio Grande do Sul, Brasil. Comum Mus Ci Tecnol Pontif Univ Rio Grande do Sul, Porto Alegre, 7: 41150.

Lema T. and Fabián-Beurmann ME. 1977. Levantamento preliminar dos répteis da região da fronteira Brasil-Uruguay. Iheringia (Zool) 50: 61-92.

Lema T, Fabián-Beurmann ME, Araujo ML, Alves MLM AND VieIRA MI. 1980. Lista de répteis encontrados na região da Grande Porto Alegre, estado do Rio Grande do Sul, Brasil. Iheringia (Zool) 55: 27-36.

*Lema T, Vieira MI and Araujo ML. 1984. Fauna reptiliana do norte da Grande Porto Alegre, Rio Grande do Sul, Brasil. Rev Brasil Zool 2(4): 203-227.

Lescure J. 1986. Amphibiens et reptiles de la bande côtière en Guyane Française, p. 111-118 in Le lit- toral guyanais. Fragilité de l'environment. Colloque Sepanguy-Sepanrit, Cayenne.

LEYNAUd GC AND BuCHER EH. 1999. La fauna de serpientes del Chaco sudamericano: diversidad, distribución geográfica y estado de conservación. Misc Acad Nac Ci (Córdoba, Argentina) 98: 3-45.

Lichtenstein MHK. 1822. Die Werke von Marcgrave und Piso über die Naturgeschichte Brasiliens erläutert aus den Wieder aufgefundenen OriginalAbbildungen (Fortsetzung). Abh. K. Akad. Wiss. Berlin 1820-1821: 238-254. (p. 75-133 of the Brasilian edition, translated and commented by Oliverio Pinto, Brasiliensia Documenta II. 1961).

*Lichtenstein H. 1856. Nomenclator Reptilium et Amphibiorum, Musei Zoologici Berolinensis. Berlin: Königl Akad Wiss. iv + 48p.

LIDTH DE JEUdE TW vAN. 1887. On a collection of reptiles and fishes from the West Indies. Notes Leyden Mus 9: 129-139.

LidTh de Jeude TW van. 1898. Muséum d'Histoire Naturelle des Pays-Bas. 10(2): Catalogue ostéologique des poissons, reptiles et amphibiens. Leiden: Brill EJ $54+52+9$ p.

LiLlo M. 1889. Enumeración y descripción de las espécies animales com las costumbres y daños o beneficios que ocasionan las más caracteristicas, p. 73-111 in Apuntes sobre la fauna de Tucumán. Bol Oficina Quimica Univ Tucumán.

Lima-Verde JS. 1974. Fisioecologia e etologia de algumas serpentes da Chapada do Apodí, estados do Ceará e Rio Grande do Norte (Brasil): Bol Zool Biol Mar. (S. Paulo) 28 (1971): 189-238. Reprinted in Caatinga (Mossoró) 1(1): 21-56, 1976.

LinNAEus C. 1749. Amoenitates academicae, seu dissertationes variae... 1. Lugduni Batavorum (Leiden): Cornelius Haak. (1) $+610+(9)$ p. Dissertationes zoologicae. Amphibia Gyllenborgiana, resp. Barth. Rudolphus Hast, p. 520-555 (originally published at Uppsala, 1745). Surinamensia Grilliana, resp. P. Sundius, p. 489-519 (orig. Stockholm, 1748). Museum Adolphum-Fridericianum (Museum Principis), resp. Laurentius Balk, p. 556-610 (orig. Uppsala, 1746).

Linnaeus C. 1754. Museum S.R.M. Adolphi Friderici Regis... in quo animalia rariora imprimis et exotica... describuntur... Stockholm: xxx $+96+(8)$ p. 
LiNNAEUs C. 1758. Systema Naturae per regna tria naturae secundum classes, ordines, genera, species cum characteribus, differentiis, synonymis, locis. Tomus I. Editio Decima, reformata. Stockholm: Laur. Salvius. 824 p.

LinNAEus C. 1766. Systema Naturae per regna tria Naturae... Editio duodecima, reformata. Tomus I. Stockholm: Laurentius Salvius. Facsimile reprint, 1963, The Ohio Herpetological Society.

Lira-DA-Silva RM, Casais-e-Silva LL, Queiroz IB AND Nunes TB. 1994. Contribuições à biologia de serpentes da Bahia, Brasil. 1. Viviparos. Rev Brasil Zool 11(2): 187-193.

*Lohmeyer C. 1882. Systematische Uebersicht der Arten der Reptilien und Amphibien des Museums der Naturforschende Gesellschaft zu Emden Jahresb Naturf. Ges. Emden 66: 1-19.

LÖNNBERG E. 1896. Linnean type specimens of birds, reptiles, batrachians and fishes in the Zoological Museum of the R. University in Uppsala. Bih t K Svenska Vet- Akad Handl 22(4) art. 1: 45p.

Lopes RA, Valeri V and Oliveira C. 1972. Histochemical study of mucopolysaccharides in the lacrymal gland of Crotalus durissus terrificus (Ophidea Viperidade). Ann Histochim 17: 305-310.

*Lopes RA, Oliveira C, Campos GM and Barros JM. 1975a. A glândula de Harder de alguns ofídios e lagartos brasileiros. Ci Cult (S. Paulo) 27(7) Supl.: 278-279. (Abstract).

*Lopes RA, Oliveira C, Campos GM and Barros JM. 1975b. Estudo morfológico e histoquímico da glândula de Harder de alguns répteis brasileiros. I. Ophidea. Mem Inst Butantan 38 (1974): 41-50.

*Machado O. 1943. Catálogo sistemático dos animais urticantes e peçonhentos do Brasil. Bol Inst Vital Brazil 25: 41-55.

*Machado O. 1945. Estudo comparativo das crotalídeas do Brasil. Bol Inst Vital Brazil 5(2): 47-66.

Magalhães O. 1922. Contribuição para o estudo dos ophidios brasileiros. Fol Med (Rio de Janeiro) 3(11): 81-82.

Magalhães O. 1925. Contribuição para o estudo dos ophidios brasileiros. Mem Inst Oswaldo Cruz 18(1): 151-161.

Marcgrave G. 1648. Historia naturalis Brasiliae. Aus- picio et beneficio Illustriss. I. Mauritii Com. Nassau... non tantum plantae et animalia, sed et indigenarum morbi, ingenia et mores describuntur et iconibus supra quingentas illustrantur. Leiden: Franciscus Hackium; Amsterdam: Lud. Elzevirium. 293 $+(4) \mathrm{p}$.

Marcuzzi G. 1950. Ofidios existentes en las colecciones de los museos de Caracas (Venezuela). Noved. Cient. (Contrib. Ocas. Mus Hist. Nat La Salle) Zool 3: $20 \mathrm{p}$.

*Marelli CA. 1931. Los vertebrados exhibidos en los zoológicos del Plata. Mem Jard Zool La Plata 4: 186-201.

Martinez AM, Martinez RA and Montanelli SB. 1992. Actualización de la distribución de los ofidios venenosos (Crotalidae y Elapidae) de la Provincia de Misiones (Argentina) y su relación con la distribución de suero antiofídico. Acta Zool Lillo 41 (Actas I Congr. Arg. I Congr Sudamer Herp): 307-310.

*McCoy CJ ANd Richmond N. 1966. Herpetological type-specimens in Carnegie Museum. Ann Carnegie Mus 38: 233-264.

MCCRANIE JR. 1980. Crotalus adamanteus Beauvois. Eastern Diamondback rattlesnake. Cat Amer Amph Rept 252: 1-2.

MCCranIE JR. 1984. Crotalus vegrandis Klauber. Uracoan rattlesnake. Cat Amer Amph Rept 350: 1-2.

McCranie JM. 1993. Crotalus durissus Linnaeus. Neotropical Rattlesnake. Cat Amer Amph Rept 577: 111.

McCranie JM and WiLson LD. 1979. Commentary on taxonomic practice in regional herpetological publications: A review of A preliminary account of the rattlesnakes with the description of four new subspecies by Herbert S. Harris, JR. and Robert S. Simons (1978), Bull Maryland Herpetol. Soc 14(3): 105-211), with comments on other Harris and Simmons rattlesnake papers. Herp Rev 10(1): 18-21.

McDiarmid RW, CAmpbell JA ANd Touré TA. 1999. Snakes species of the world. Vol. 1. Washington, D.C.: The Herpetologists' League. xi +509 p.

*Medem F. 1969. El desarrollo de la herpetologia en Colombia. Rev Acad Colomb Ci 13(50) (1968): 149199.

MeEK SE. 1910. Notes on batrachians and reptiles from 
the islands north of Venezuela. Publ Field Mus Nat Hist (Zool) 7(12): 415-418 (Publ. 148).

*Meneghel MD, Melgarejo AR and Achaval F. 1989. Clave para determinación de los reptiles del Uruguay. Montevideo: Universidad de la Republica, Facultad de Humanidad y Ciencias.

Meneses-G. O. 1974. Ofidios y ofidismo en el Perú. I. Las serpientes venenosas del Perú. Rev Inst Zoonos Invest Pecuar 2(3-4): 79-84.

Merrem B. 1820. Versuch eines Systems der Amphibien. Marburg: J.C. Krieger. (Tentamen systematis amphibiorum).

Mertens R. 1941. Vom Schwanze der Schlangen. Natur u. Volk 71(12): 543-553.

*Mertens R. 1955. Vom brasilienischen Schlangeninstitut Butantan. Natur u. Volk 85: 229-240.

Michaelis CF. 1785. Ueber die Klapperschlange, ein Brief des Leibmedicus Michaelis an Hrn. Prof. Lichtenberg. Götting. Mag. Wiss. Litt. 4(1): 90128. (facsimile reprint 1977, Otto Zeller Verlag, Osnabrück).

*Migone LE. 1929. Apuntes de climatologia y nosografia medica del Paraguay. Rev Soc Ci Paraguay 2(5): 203-222.

Mijares-Urrutia A and Arends-R. A. 2000. Herpetofauna of estado Falcón, northwestern Venezuela: a checklist with geographical and ecological data. Smithson Herp Inf Serv 123: 1-30.

Milá de la Roca F. 1932. Introducción al estudio de los ofidios de Venezuela. Bol Soc Venezol Ci Nat 1(10): 381-392.

Miranda JR and Miranda EE. 1982. Métodos de avaliação faunística em território limitado. $\mathrm{O}$ caso de Ouricurí, Pe. EMBRAPA. Centro de Pesquisa Agropecuária do Trópico Semi-árido, Documentos 11: $28 \mathrm{p}$.

Miranda ME, Tio-Vallejo M and Grisolia CS. 1985. Nota sobre casos de albinismo en ofidios argentinos. Historia Natural, Corrientes, 5(15): 121-124.

*Mocquard F. 1909. Livraison 17, p. 933-1012 in A. Duméril, Bocourt \& Mocquard, Mission scientifique au Mexique et dans l'Amerique Centrale. Études sur les reptiles. Paris: Imprimerie Nationale. Facsimile edition 1978 Arno Press, New York.

Montanelli SB And Acosta S. 1991. Lista preliminar de la herpetofauna del Parque Nacional Iguazu. Bol ASoc Herp. Argent. 7(2): 9-10.

*Moore GM. (ED). 1968. Poisonous snakes of the world. A manual for use by U.S. amphibious forces. Second edition. Washington, D.C.: Department of the Navy, Bureau of Medicine and Surgery (Navmed P-5099). viii $+203 p$.

Morais ZMB AND MoraIs JB. 1987. Lista preliminar de répteis da Estação Ecológica do Tapacurá, Pernambuco. An Soc Nordest. Zool 1(1): 247-256. (Trabalhos do V-VI Encontro de Zoologia do Nordeste).

*MuIR JH. 1984. Captive reproduction of the Uracoan rattlesnake, Crotalus vegrandis. Bull Chicago Herp Soc 19(4): 131-133.

Müller F. 1878. Katalog der im Museum und Universitätskabinet zu Basel aufgestellen Amphibien und Reptilien. Verh Nat Ges Basel 6: 561-709.

Müller F. 1892. Siebenter Nachtrag zum Katalog der herpetologischen Sammlung des Basler Museums. Verh Naturf Ges Basel 10: 195-215. (Festschr. 75. Best Naturf Ges Basel).

*Müller L. 1927. Amphibien und Reptilien der Ausbeute Prof. Breslau's in Brasilien 1913-14. Abh Senckenberg Ges 40(3): 259-304.

*Müller P. 1969a. Herpetologische Beobachtungen auf der Insel Marajo. D Aquar Terr Z 22(4): 117-121.

*MüLler P. 1969b. Vertebratenfauna brasilianischer Inseln als Indikatoren für glaziale und postglaziale Vegetationsfluktuationen. Zool Anz Suppl 33: 97-107.

*Müller P. 1971a. Herpetologische Reiseeindrücke aus Brasilien. Salamandra 7(1): 9-30.

*Müller P. 1971b. Ausbreitungszentren und Evolution in der Neotropis. Mitt Biogeogr Abt Geogr Inst Univ Saarlandes 1: 1-20.

*Müller P. 1972a. Der Neotropische Artenreichtum als biogeographisches Problem. Zool Med Leiden 47: 88-110.

*Müller P. 1972b. Ausbreitungszentren in der Neotropis. Naturw Rundsch 25(7): 267-270.

*Murphy JB, Mitchell LA. and Campbell JA. 1979. Miscellaneous notes on the reproductive biology of reptiles. III. The Uracoan rattlesnake, Crotalus vegrandis Klauber (Serpentes, Viperidae). J Herp 13(3): 373-374.

Museum Imperiale Petropolitanum. 1742. Vol. 1 
Pars prima qua continentur res naturales ex regno animali. St. Petersburg: Academy of Sciences.

Nascimento FP, Ávila-Pires TCS and Cunha OR. 1987. Os répteis da área de Carajás, Pará, Brasil (Squamata). II. Bol Mus Para Emilio Goeldi (Zool) 3(1): 33-65.

Nascimento FP, Ávila-Pires TCS and Cunha OR. 1988. Répteis Squamata de Rondônia e Mato Grosso coletados através do Programa Polonoroeste. Bol Mus Para Emilio Goeldi (4) 1: 21-66.

Nascimento FP, Ávila-Pires TCS, SAntos INFF AND Lima ACM. 1991. Répteis de Marajó e Mexiana, Pará, Brasil. I. Revisão bibliográfica e novos registros. Bol Mus Para Emilio Goeldi (Zool) 7(1): $25-41$.

*NicÉforo-Maria Hno. 1929. Observaciones acerca de algunos nombres cientificos que emplea el Doctor Evaristo Garcia en su obra titulada: "Los Ofidios Venenosos del Cauca', Rev Soc Colomb Ci Nat 18(103): 189-191.

Nicéforo-Maria Hno. 1930. Los reptiles de Villavicencio en el Museo de La Salle. Rev Soc Colomb Cienc Nat 19(105): 40-54.

NicÉforo-Maria Hno. 1933. Las serpientes de Villavicencio, p. 199-237 in Libro Comemorativo del segundo centenario de don José Celestino Mutis y Bosio, 1732-1932. Bogotá: Imprenta Nacional.

NicÉForo-Maria HnO. 1942. Los ofidios de Colombia. Rev Acad Colomb Ci 5(17): 84-101, 3 pls.

Nickerson MA AND MAys CE. 1968. More aberrations in the color patterns of rattlesnakes (genus Crotalus). Wasmann J Biol 26(1): 125-131.

Nieremberg JE. 1635. Historia naturae, maxime peregrinae, libri xvi distincta... Antwerp: (vi) + $502+$ (102)p.

*Norman DR. 1994. Anfibios y reptiles del Chaco Paraguayo. Tomo I. (Amphibians and reptiles of the Paraguayan Chaco. Volume 1). San José, Costa Rica. Author's edition. vi + 138 (Spanish), 139-259 (English).

Olearius A. 1674. Gottorfische Kunst-Kammer worinnen Allerhand ungemeine Sachen, so theils die Natur, theils künstliche Händer hervorgebracht und bereitet est. Schleswig: $x+80$ p, 36 pls.

Oppel M. 1810. Mémoire sur la classification des rep- tiles. Ordre II. Reptiles à écailles. Section II. Ophidiens. Ann Mus Nat Hist Paris 16: 254-295, 376-393.

Oppel M. 1811a. Die Ordnungen, Familien und Gattungen der Reptilien als Prodrom einer Naturgeschichte derselben. München. Joseph Lindauer. xii +87 p.

Oppel M. 1811b. Mémoire sur la classification des reptiles. Ordre II. Reptiles à écailles. Section II. Ophidiens. Ann. Mus Hist. Nat Paris 16: 254-295, 376-393 (1810) (for date see Vanzolini 1977: 18).

*Orcés G. 1942. Los ofidios venenosos del Ecuador (1a. parte). Flora (Quito) 2: 147-155.

*Orcés G. 1943. Los ofidios venenosos del Ecuador (conclusión). Flora, Quito, 3: 165-170.

OrcÉs G. 1948. Notas sobre los ofidios venenosos del Ecuador. Publ Esc Politecn Nac (Quito) 3: 231-250.

Ortenburger AI. 1922. Some cases of albinism in snakes. Copeia 113: 90.

O’Shea M. 1989. The herpetofauna of Ilha de Maracá, state of Roraima, Northern Brasil. Reptiles: Proc. 1988 UK Herp Symposium on Captive Breeding: 5172. Brit. Herp. Soc.

PARKER HW. 1935. The frogs, lizards and snakes of British Guiana. Proc Zool Soc London 1935: 505 530.

*Pefaur JE. 1992. Checklist and bibliography (196085 ) of the Venezuelan herpetofauna. Smithson Herp Inf Serv 89: 1-54.

Peracca MG. 1895. Viaggio del dott. Alfredo Borelli nella Repubblica Argentina e nel Paraguay. Boll. Mus Zool Torino 10(195): 1-32.

Peracca MG. 1904. Viaggio del Dr. A. Borelli nel Matto Grosso brasiliano e nel Paraguay, 1899. IX. Rettili ed Amfibi. Boll Mus Zool Torino 19(460): 1-15.

Perez MR, Rada de M. D and Bello De L. R. 1997. Contribución al conocimiento de Crotalus durissus cumanensis y Crotalus pifanorum (Serpentes, Viperidae). Acta Biol Venez 17(1): 25-35.

Perez-Bidó MR. 1992. Contribución al conocimiento taxonomico de Crotalus durissus cumanensis y Crotalus pifanorum (Serpentes, Viperidae). Trabajo Especial de Grado, Universidad Central de Venezuela. $(12)+91 p$.

Perez-Santos C. 1986. Las serpientes del Atlantico. Madrid: Museo Nacional de Ciencias Naturales. $83 p$. 
*Perez-Santos C and Moreno AG. 1986. Distribución altitudinal de las serpientes en Colombia. Rev Españ Herp 1: 9-27.

*Perez-Santos C and Moreno AG. 1988. Ofidios de Colombia. Monogr Mus Reg Sci Nat Torino VI: 517 p., pls.

Peters JA. 1960. The snakes of Ecuador. A check list and key. Bull Mus Comp Zool 122(9): 489-541.

Peters JA. 1967. On Venezuelan snakes. La taxonomia y zoogeografia de los ofidios de Venezuela by Janis A. Roze. Copeia 1967(2): 496-498.

Peters JA and Orejas-Miranda B. 1986. Catalogue of the Neotropical Squamata. Part I, Snakes. Originally published as Bull U.S. Nat Mus 297 (1970): viii $+347 \mathrm{p}$. Revised edition, with new material by PE Vanzolini: $26+(\mathrm{v}$-viii $)+347 \mathrm{p}$.

Peters W. 1877. Sammlung des Hrn. Dr. Carl Sachs in Venezuela. Monatsber Akad Wiss Berlin 1877: 457-460, pl.

Pieters FJM. 1980. Notes on the menagerie and zoological cabinet of Stadholder William V of Holland, directed by Aernout Vosmaer. J Soc Bibl Nat Hist 9(4): 53-563.

*Pifano-C. F. 1945. El empozoñamiento ofídico en el Valle del Yaracuy. Publ Asoc Med Yaracuy (San Felipe, Venezuela) 1(2): 69-87.

Piso G. [PIes W] 1648. Historia naturalis Brasiliae, auspicio et beneficio Ilustriss. I. Mauritii Com. Nassau... Leide: F. Hack; Amsterdam: L. Elzevir.

*Piza ST. 1928. O Cascavel (Crotalus terrificus). Ceres (S. Paulo) 4(8): 317-318.

*Piza ST. 1928. Sobre a impropriedade do vocábulo “crotalus' para designar um genero de ophidios. Rev Agric Piracicaba 3(7-8): 43.

*Piza ST. 1930. Cobras venenosas. Rev Agric Piracicaba 5(1-2): 41-45.

*PIza ST. 1930. As cobras venenosas e o problema ofídico em S. Paulo. Bol Agric. (S. Paulo) 31(5-6): 307-390.

*Pope CH. 1944a. The poisonous snakes of the New World. New York: New York. New York Zool Soc $47 \mathrm{p}$.

*Pope CH. 1944b. The poisonous snakes of the New World. Part 3. Anim. Kingd 47(6): 143-152.
*Posada-Arango A. 1889. Apuntamientos para la ofiologia colombiana. An Acad Med Medellin 2(2): 43-49.

*Posada-Arango A. 1889. Note sur quelques solénoglyphes de Colombie. Bull Soc Zool France 14: 343345.

*Posada-Arango A. 1909. Las serpientes, pp. 252284 in Estudios cientificos del doctor Andrés Posada, com algunos escritos suyos sobre diversos temas y com ilustraciones ó grabados. Medellin: Imprensa Oficial.

Prado A ANd Barros FP. 1940. Duas cascaveis albinas do Brasil. Ciencia (Mexico) 1(6): 255 (republished in 1941, Mem Inst Butantan 14 (1940): 31-33, pl.)

*Pregill GK and Berrian JE. 1984. Type specimens of amphibians and reptiles in the San Diego Soc Nat Hist 20(10): 151-164.

Prüst E. 1984. Albinism in snakes. Litt Serp 4: 6-15.

Quelch JJ. 1898. The poisonous snakes of British Guiana. Timehri (2) 12: 26-36.

RAmo C AND Busto B. 1990. Inventario herpetológico (anfibios y reptiles) de las sabanas inundables del Modulo Fernando Corrales (Mantecal) Estado Apure. Mem Soc Ci Nat La Salle (Caracas) 49-50 (131-134): 287-308.

RAY J. 1693. Synopsis methodica animalium quadrupedum et serpentini generis. London: (xvi) $+336+$ (18)p. (Fac-simile edition, Arno Press, 1978).

Renault L and Schreiber G. 1951. Considerações sobre albinismo em cascavel. Folia Clin Biol (S. Paulo) 16(1) (1949-1950): 91-92.

*Ringuelet R and Aramburu RH. 1957. Enumeración sistemática de los vertebrados de la provincia de Buenos Aires. Buenos Aires: Ministerio de Asuntos Agrarios. 94p.

Rivero-Blanco C and Dixon JR. 1979. Origin and distribution of the herpetofauna of the dry lowland regions of northern South America, p. 281-298 in Duellman WE, ed., The South American herpetofauna: its origin, evolution and dispersal. Monogr Mus Nat Hist Univ Kansas 7: 485p.

*Romano-Hoge SARWL. 1990. Principais serpentes de interesse médico. Reconhecimento. Distribuição geográfica no continente americano., p. 1-45 in B. Soerensen, ed., Animais peçonhentos. Reconheci- 
mento - distribuição geográfica - produção de soros - clínica e tratamento dos envenenamentos. S. Paulo: Livraria Atheneu Editora.

*Rosén N. 1905. List of the snakes in the zoological museums of Lund and Malmö, with descriptions of new species and a new genus. Ann Mag Mag Hist (7) $15: 168-181$.

Roze JA. 1952. Colección de reptiles del Profesor Scorza, de Venezuela. Acta Biol Venezuel 1 (5): 93114.

Roze JA. 1953. Ofidios de Camuri Chico, Macuto, D.F., Venezuela, colectados por el Rvdo. Padre Cornelius Vogl. Bol Soc Venezol Ci 14(79): 200-211.

Roze JA. 1966. La taxonomia y zoogeografia de los ofidios en Venezuela. Caracas: Universidad Central de Venezuela. 362p.

Rubio M. 1998. Rattlesnake: portrait of a predator. Washington and London: Smithsonian Institution Press. xxxi $+240 p$.

RuIz JM. 1952. Sobre a distinção genérica dos Crotalidae (Ophidia: Crotaloidea), baseada em alguns caracteres osteológicos (Nota preliminar). Mem Inst Butantan 23 (1951): 109-114.

*Ruschi A. 1966. Lista de répteis do estado do Espírito Santo. Bol Mus Biol "Prof. Mello-Leitão" (Zool) 26A: $6 p$.

Ruthven AG. 1922. The amphibians and reptiles of the Sierra Nevada de Santa Marta, Colombia. Misc Publ Mus Zool Univ Michigan 8: 1-69, pls., map.

Ruthven AG. 1923. The reptiles of the Dutch Leeward Islands. Occ Pap Mus Zool Univ Michigan 143: 10p.

Sage RD and Capredoni EE. 1971. La distribución de la cascabel (Crotalus durissus terrificus Laurentius) en la Argentina y su significado zoogeográfico (Reptilia, Serpentes). Neotropica 17(54): 133-136.

*Sandner-Montilla F. 1965. Manual de las serpientes ponzoñosas de Venezuela. Caracas: Gema. 108p.

*Sandner-Montilla F. 1975. Manual de las serpientes ponzoñosas de Venezuela. 2nd ed. Caracas: Miguel Angel Garcia y hijo. 111p.

Sandner-Montilla F. 1980. Una nueva especie del género Crotalus (Serpentes, Crotalidae, Crotalinae) del sur del estado Guárico, Venezuela. Mem Cient Ofidiol. 5: 1-12.

Sandner-Montilla F. 1983. Serpientes Crotalinae de
Venezuela. Mem Inst Butantan 46 (1982): 193-194. (Primeiro Simpósio Internacional sobre Serpentes em geral e artrópodes peçonhentos).

SANDNER-Montilla F. 1985. Edición dedicada al mas insigne herpetólogo de todos los tiempos: el Professor Doutor Afranio do Amaral. Mem Cient Ofidiol, Caracas, 7: 77p.

*Santos S, Ferreira ILL and Puorto G. 1990. Ritual de combate em Crotalus durissus - Serpentes Viperidae. An Acad Bras Cienc 62(4): 418. (abstract).

SAntos SMA AND Germano VG. 1996. Natural history notes. Crotalus durissus (Neotropical rattlesnake). Prey Herp Rev 27(3): 143.

*SAPORITi EJ. 1946. Ampliación de la distribución geográfica de ofídios argentinos. Notas Mus La Plata 11 Zool 95: 311-315.

Sazima I ANd Di Bernardo M. 1992. Albinismo em serpentes neotropicais. Mem Inst Butantan 53(2) (1991): 167-173.

SCHENBERG S. 1959. Geographical pattern of crotamine distribution in the same rattlesnake subspecies. Science 129: 1361-1363.

SChenberg S. 1960. Análise da crotamina no veneno individual de cascavéis recebidas pelo Instituto $\mathrm{Bu}$ tantan. Mem Inst Butantan 29 (1959): 213-226.

Schenkel E. 1901. Achter Nachtrag zum Katalog der herpetologischen Sammlung des Basler Museums. Verh Naturf Ges Basel 13: 142-199.

Schinz HR. 1822. Das Thierreich nach dem Bau der Thiere als Grundlage ihrer Naturgeschihchte und der vergleichende Anatomie von dem Herrn Ritter von Cuvier... vol. 2. Stuttgart und Tübingen: J.G. Cotta.

SchINZ HR. 1835. Naturgeschichte und Abbildungen der Reptilien. Leipzig: Wiedmann (for date see Vanzolini 1977: 48).

Schlegel H. 1837-1843. Abbildungen neuer oder unvollständig bekannter Amphibien, nach der Natur oder dem Leben entworfen, herausgegeben und mit einem erläuternden Texte begleit. xiv $+141 p$. Düsseldorf: Arnz.

SCHLEgel H. 1837. Essai sur la physionomie des serpens. Amsterdam: Schonekat MH La Haye: Kips J, Hz J et van Stockum WP. 2 vols., atlas.

ScHMIDT KP. 1953. A check list of North American am- 
phibians and reptiles. American Society of Ichthyologists and Herpetologists. vii +280 p.

Schmidt KP AND Walker WF. 1943. Peruvian snakes from the University of Arequipa. Publ Field Mus Nat Hist (Zool) 24(26): 279-296.

SCHNEE P. 1900. Über eine Sammlung südbrasilianischer Reptilien und Amphibien, nebst Beschreibung einer neuen Schildkröte (Platemys Werneri). Zool Anz 23: 461-464.

*SChOuten GB. 1931. Contribuciones al conocimiento de la fauna herpetologica del Paraguay y de los paises limitrofes. Rev Soc Cient Paraguay 3(1): 5-32.

*Schouten GB. 1937. Fauna herpetológica del Paraguay Novena Reun Soc Argent Patol Region 2: 12181232.

*Schupp A. 1913. As cobras do Rio Grande do Sul. Petrópolis, Rio de Janeiro: Typographia "Vozes de Petropolis', 80p.

Scott NJ AND LovetT JW. 1975. A collection of amphibians and reptiles from the Chaco of Paraguay. Univ Connecticut Occas Pap (Biol) 2(16): 257-266.

SEBA A. 1734-1765. Locupletissimi rerum naturalium thesauri accurata descriptio, et iconibus artificiosissimi expressio, per universam physices historia. 4 vols. Amsterdam: J Wetstein, G Smith \& J JanssonWaesberg.

SERIÉ P. 1919a. Notas sobre las serpientes venenosas de la Argentina. Primera Reunión Nac Soc Argent Ci Nat (Buenos Aires, 1916): 400-417, pls.

SERIÉ P. 1919b. Enumeración de los ofidios de Tucuman. Primera Reun Nac Soc Argent Ci Nat, Buenos Aires 1916: 418-420.

Serié P. 1921. Catálogo de los ofidios argentinos. An Soc Ci Argent 92: 145-192.

*Serié P. 1936. Nueva enumeración sistemática y distribución de los ofidios argentinos. Obra Cincuentenario Mus La Plata 2: 33-61.

*Serié P. 1937. Los crotálidos de la Argentina. Rev Chil Hist Nat 40: 47-53.

Shaw G. 1802. General Zoology, or Systematic Natural History. Vol. 3, 2 parts, Amphibia. London: G. Kearsley.

Sherborn CD. 1899. A note on the date of the parts of 'Humboldt and Bonpland's Voyage: Observations de Zoologie'. Ann Mag Nat Hist (7) 3: 428.
SHERBorN CD. 1922. Index animalium sive index nominum quae ab A.D. MDCCLVIII generibus et speciebus animalium imposita sunt. Sectio secunda a calendis ianuariis, MDCCI usque ad finem decembris, MDCCCCL. 9 vols. London: British Museum.

Shreve B. 1947. On Venezuelan reptiles and amphibians collected by Dr. HG Kugler. Bull Mus Comp Zool 99(5): 517-537.

SILVA NJ JR. 1993. The snakes from Samuel hydroelectric power plant, Rondônia, Brazil. Herp Nat Hist 1(1): $37-86$.

Smith HM ANd TAYlor EH. 1950. Type localities of Mexican reptiles and amphibians. Univ Kansas Sci Bull 33(2) 8: 313-380.

STARACE F. 1998. Guide des serpents et amphisbènes de Guyane. Guadeloupe, French Guiana: Ibis Rouge Editions. 449p.

*Staton MA And Dixon JR. 1977. The herpetofauna of the central llanos of Venezuela: noteworthy records, a tentative checklist and ecological notes. J Herp 11(1): 17-24.

Stejneger L. 1936. Types of the amphibian and reptilian genera proposed by Laurenti in 1768. Copeia 1936(3): 133-141.

STILle B. 1987. Dorsal scale microdermatoglyphics and rattlesnake (Crotalus and Sistrurus) phylogeny (Reptilia: Viperidae: Crotalinae). Herpetologica 43(1): 98-104.

Suckow GA. 1798. Anfangsgrunde der theoretischen und angewandten Naturgeschichte der Thiere. Dritter Theil, von den Amphibien. Leipzig: Weissmann. $298 \mathrm{p}$.

Tello J. 1968. Historia Natural de Caracas. Caracas: Concejo Municipal del Distrito Federal. Ediciones del Cuatricentenario de Caracas. 325p

*Themido AA. 1945. Répteis do Brasil (Catálogo das coleções do Museu Zoológico de Coimbra). Mem Est Mus Zool Univ Coimbra 168: 1-15.

Thireau M. 1991. Types and historically important specimens of rattlesnakes in the Muséum National d'Histoire Naturelle (Paris). Smithsonian Herp Inf Serv 87: $1-10$

Thomas O. 1892. On the probable identity of certain specimens, formerly in the Lidth de Jeude collection, and now in the British Museum, with those figured 
by Albert Seba in his "Thesaurus" of 1734. Proc Roy Soc. London 22: 309-317.

*Trinco LA And Smith HM. 1972. The karyology of ophidians: a review. Trans Kansas Acad Sci 74(2) (1971): 138-146.

Troschel FH. 1848. Amphibien, p. 645-661 in Schomburgk R, Versuch einer Zusammenstellung der Fauna und Flora von Britisch-Guiana.

TschudI JJ DE. 1845. Reptilium conspectus quae in Republica Peruana reperiuntur et pleraque observata vel collecta sunt in itinere a... Arch. Naturg 11(1): 150-170 (facsimile reprint 1968 Society for the Study of Amphibians and Reptiles).

TsCHUDI JJ von 1846. Untersuchungen über die Fauna Peruana. Herpetologie. 80 pp. St. Gallen: Scheitlin und Zollikofer.

Tyson E. 1683. Vipera Caudi-sona Americana, or the anatomy of a rattle-snake dissected at the repository of the Royal Society in January 1682/3. Phil Trans Roy Soc London 12(144): 25-58.

Van Denburgh J. 1922 The reptiles of western North America. Vol. II. Snakes and turtles. Occas Pap California Acad Sci 10: 615-1028.

VAnzolini PE. 1948. Notas sobre os ofidios e lagartos da Cachoeira de Emas, município de Pirassununga, estado de S. Paulo. Rev Brasil. Biol 8(3): 377-400.

VANZOLINI PE. 1977. An annotated bibliography of the land and fresh-water reptiles of South America (17581975). Vol 1 (1758-1900). S. Paulo: Museu de Zoologia, Universidade de S. Paulo. iv + 316p.

Vanzolini PE. 1981a. The scientific and political contexts of the Bavarian Expedition to Brasil. Introduction, p. ix-xxix in Adler K., ed., Herpetology of Brasil, by von Spix JB and Wagler JC, facsimile reprint, Society for the Study of Amphibians and Reptiles.

VANZOLINI PE. 1981b. Reptilia, p. 246-261 in Hurlbert SH, Rodrigues G and Santos ND, eds., Aquatic biota of tropical South America, Part 2, Anarthropoda. San Diego: San Diego State University.

Vanzolini PE, Ramos-Costa AMM and Vitt LJ. 1980. Repteis das Caatingas. Rio de Janeiro: Academia Brasileira de Ciências. 161p., pls.

Vaz-Ferreira R and Sierra de Soriano B. 1960. Notas sobre reptiles del Uruguay. Rev Fac Human $\mathrm{Ci}$
(Montevideo) 18: 1-55.

*Vellard J. 1928a. Importance des caractères fournis par l'hemipénis pour la classification des ophidiens. Bull Soc Zool France 53: 406-418.

*Vellard J. 1928b. O hemipenis dos ofidios. Importancia de seus caracteres para a classificação das serpentes. Bol Inst Vital Brazil 6: 1-19.

Vellard J. 1937. Variations geographiques des venin du serpent à sonnettes sud-américain, Crotalus terrificus Laur. C R Acad Sci Paris 204: 1679.

Vellard J. 1941. Serpentes venimeux du Venezuela. Ann. Sci Nat, Paris (11) 3: 193-225.

VELlaRd J. 1943. Diferenciación biologica de la cascavel sudamericana. Acta. Zool Lillo. 1: 55-88.

VELlaRd J. 1946. Morfologia del hemipenis y evolución de los ofidios. Acta Zool Lillo 3: 263-288.

Vellard J and Huidobro F. 1941. Acción comparada de diversos venenos de ofidios sobre la presión arterial. Rev Soc Argent. Biol 17(1): 72-80.

Vetencourt FH. 1960. Ofidios venenosos de Venezuela. Rev Med. Veter. Parasit. (Maracay) 18: 161-192.

Villa J And Rivas A. 1971. Tres serpientes albinas de Nicaragua. Rev Biol Trop 19(1,2): 159-163.

Vincent L. 1726. Catalogus et descriptio animalium volatilium, reptilium et aquatilium... quae in liquoribus ad vivam conservat... The Hague: $72 \mathrm{p}$.

VitT LJ AND VANGILDER LD. 1983. Ecology of a snake community in northeastern Brasil. Amph.- Rept. 4(204): 273-296.

Vosmaer A. 1767. Description d'un serpent à sonnette de l'Amerique, joliment figuré, ayant deux longues rayes noires sur la tête et sur le col;... Amsterdam 22p., 1 pl.

Vosmaer A. 1768. Beschryving van eene sierlyk geteekende, en over het Hoofd en den Hals twee lange zwarte Streepen hebbende Surinamsche Ratelslang;... Chap. V, 22p. in Natuurkundige Beschryving eener uitmuntende Vezameling van zeldsame Gedierte, bestande in Ost-en Westindische viervoetige Dieren, Vogelen en Slange,... Amsterdam.

Vuoto JA. 1995. Nueva enumeración de los ofidios (Reptilia: Serpentes) de Entre Rios, Argentina. Mem Mus “Prof. Antonio Serrano", (Paraná. Entre Rios) (N.S., Zool) 5: 1-17. 
WAGLER J. 1824. Serpentum brasiliensium species novae ou Histoire naturelle des espèces nouvelles de serpens, recueillies et observées pendant le voyage dans l'interieur du Brésil dans les années 1817, 1818, 1819, 1820,... Monaco: F.S. Hübschmann.

Wagler J. IN BoIE H. 1825. Zu Kaups über Lurche (Isis h. 5.1825). Isis von Oken 17: 1089-1090.

WAGler J. 1827. Gedrängte Bemerkungen zu Herrn Fitzingers Critik des von Spixischen brasilianischen Schlangenwerkes und über seine neue Classification der Reptilien. Isis von Oken 20: 422-428.

WAGLer J. 1830. Natürliches System der Amphibien. München \& c: J.G. Cotta. vi + 352p.

*Wagner RT. 1961. Hunting the Brazo Papayal. Bull Philadelphia Herp Soc July-August 1961: 15-16.

Warming E. 1892. Lagoa Santa. Et Bidrak til den plantengeografi. K. Dansk. Vid. Selbst. Skr. 6(3): 153-453. (Brasilian translation by A. Löfgren, 1908, Bello Horizonte, Imprensa Official do Estado de Minas Geraes. $281+2$ p.).

Weigel CE. 1783. Beytrag zur Bestimmung der Schlangenarten. Abh. Hall. Naturf. Ges. 1: 1-54.

*Werner F. 1899. Phylogenetische Studien über die Homologien und Verämderungen bei den Schlangen. Arb Zool Inst Univ Wien 11: 117-162, 3 pls.

*Werner F. 1922. Synopsis der Schlangen-familien der Amblycephalidae und Viperidae nebst Übersicht die Kleineren Familien und die Colubriden der Acrochordinengruppe. Auf Grund des Boulengerschen Schlangenkatalogs (1893-1896). Arch Naturg 88 A(8): 185-244.

*Werner F. 1929. Übersicht der Gattungen und Arten der Schlangen aus der Familie Colubridae. III. Teil. (Colubrinae). Zool Jahb (Syst.) 57: 7-196.

Weyenbergh H. 1876. The Argentine Fauna, p. 137174 in The Argentine Republic, written in German by Richard Napp, assisted by several fellow-writers for the Central Argentine Commission on the Centenary Exhibition at Philadelphia. Buenos Aires: Sociedad Anonima. iii $+563 p$.
Wied-Neuwied Maximilian, Prinz zu. 1821. Reise nach Brasilien in den Jahren 1815 bis 1817. Vol. 2. Frankfurt a.M.: H.L. Brönner.

Wied-Neuwied Maximilian, Prinz Zu. 1825. Beiträge zur Naturgeschichte von Brasilien. Vol. 1. Weimar: Gr. H.S. priv. Landes-Industrie-Comptoirs. 620p., pls.

Wied[-Neuwied] Max[imilian], Prinz zU. 1850. Brasilien. Nachträge, Berichtigungen und Zusätze zur der Beschreibung meiner Reise im östlichen Brasilien. Frankfurt am Main: Ludwig Brönner. 144p. (Brasilian translation, Rio de Janeiro, 1969, Conselho Nacional de Pesquisas).

Williams JD and Francini F. 1991. A checklist of the Argentine snakes. Boll Mus Reg Sci Nat Torino 9(1): 55-90.

DE WiTte GFR. 1930. Liste des reptiles et batraciens récoltés au Brésil par La Mission Massart (1922-23) et description de sept nouvelles espèces, pp. 213-230 in R. Bouillenne, P. Ledoux, P. Brien \& A. Navez, Une mission biologique belge au Brésil (Août 1922-Mai 1923). Bruxelles: Imprimerie Medicale et Scientifique. 261p.

WuCherer O. 1861. On the ophidians of the province of Bahia, Brazil (Part I.). Proc Zool Soc London 1861: 113-116.

*Wucherer O. 1863. Algumas observações sobre a fauna brasiliense (continuação). Periodico Inst Hist Bahia 3: 40-48.

*Wucherer O. 1867. Sobre o modo de conhecer as cobras venenosas do Brasil. Gaz Med Bahia 1(17): 193-196, pl.

YANOSKY AA. 1989. La ofidiofauna de la Reserva Ecológica El Bagual, Formosa: abundancia, utilización de los habitats y estado de situación. Cuad. Herp. (Asoc Herp Argent) 4(3): 11-14.

YuKi RN AND SANTos RM. 1996. Snakes from Marajó and Mexiana Islands. Pará state, Brazil. Bol Mus Para Emilio Goeldi (Zool) 12(1): 41-53. 